\title{
Plastic and Immobile: Unequal Intergenerational Mobility by Genetic Sensitivity Score within Sibling Pairs
}

\author{
Emily Rauscher \\ Assistant Professor of Sociology \\ Brown University
}

(C) 2017. This manuscript version is made available under the CC-BY-NC-ND 4.0

license http://creativecommons.org/licenses/by-nc-nd/4.0/

\section{Acknowledgement}

This research uses data from Add Health, a program project directed by Kathleen Mullan Harris and designed by J. Richard Udry, Peter S. Bearman, and Kathleen Mullan Harris at the University of North Carolina at Chapel Hill, and funded by grant P01-HD31921 from the Eunice Kennedy Shriver National Institute of Child Health and Human Development, with cooperative funding from 23 other federal agencies and foundations. Special acknowledgment is due Ronald R. Rindfuss and Barbara Entwisle for assistance in the original design. Information on how to obtain the Add Health data files is available on the Add Health website (http://www.cpc.unc.edu/addhealth). No direct support was received from grant P01-HD31921 for this analysis.

This research was supported by the University of Wisconsin - Institute for Research on Poverty. I am grateful for constructive feedback from Jason Fletcher, Katherine Magnuson, and others at the Institute for Research on Poverty workshop. 


\begin{abstract}
A growing body of evidence suggests that genotypes previously construed as risky may instead make individuals more sensitive to context. This differential susceptibility model could help explain why some children follow in their parents' financial footsteps, reproducing inequality between generations, while others experience greater mobility. Contrary to traditional biological explanations for intergenerational transmission, the differential susceptibility model suggests genotype may moderate parent-child similarity. I use family fixed effects models of sibling data from the National Longitudinal Survey of Adolescent to Adult Health (as well as supplemental analysis of Wisconsin Longitudinal Study data) to investigate whether an index of sensitive genotypes moderates parent-child economic similarity. Comparisons of full, same sex siblings hold constant parental characteristics and address the non-random distribution of genotype that reduces internal validity in nationally representative samples. Compared to their same sex sibling and across multiple measures of young adult financial standing, evidence suggests individuals with more copies of sensitive genotypes achieve lower attainment if they are from low income contexts but fare better from high income contexts. This genetic sensitivity entails lower intergenerational mobility and supports the differential susceptibility model. Results of this study contradict simplistic genetic explanations for intergenerational inequality; financial standing is not genetically determined and policies could improve opportunity.
\end{abstract}




\section{Introduction}

A recent New York Times article - "The Mixed-Up Brothers of Bogotá" by Susan Dominus (2015) - chronicles the lives of two pairs of identical twins in Colombia who were switched shortly after birth and raised as fraternal twins. One pair grew up in a rural setting, with poor parents and limited opportunity for schooling, while the other pair grew up in an urban setting with a struggling single mother but more opportunity for mobility. The two boys raised in the city now have professional occupations (accountant and engineer), while the two boys raised in the country are butchers. The identical twins share common behaviors, even after 27 years of living apart, but the story illustrates how social context can trump genes and determine financial standing as a young adult.

Although compelling, this anecdotal story offers little generalizable evidence about how genes and environment may conjointly impact financial standing. Traditional biological explanations for intergenerational transmission of financial standing suggest genes mediate parent-child similarity (Clark 2014). That is, a simplistic genetic argument suggests that parents pass financial standing on to their children (at least partly) through their genes. The sociological interpretation, however, suggests the effects of the genes one inherits depend on social context or environment. As Conley (2011: 231) describes it, “A gene for aggression lands you in prison if you are from the ghetto, but in the board room if you are manor born."

Does environment - specifically parental income - moderate the relationship between genes and financial standing? Recent advances in gene-environment interaction (GxE) research suggest that certain genotypes increase sensitivity to environments, increasing variation in outcomes rather than simply risk of negative outcomes (Belsky 2013, 2005; Belsky and Pluess 2009; Belsky et al. 2007). Called the differential susceptibility model or the biological 
sensitivity to context (BSC) hypothesis (Boyce and Ellis 2005; Ellis and Boyce 2008), this model suggests genotypes previously considered risky may confer risk or benefit, depending on the environment. This differential susceptibility model is appealing because it could help explain the survival of these genotypes in human populations (Belsky 2005). Though potentially risky in a negative environment, in a particularly supportive environment carriers of sensitive genotypes could achieve even more positive outcomes than those with more stable genotypes. Sensitive genotypes, in other words, make individuals carrying them more dependent on the characteristics of their environment than others who carry more stable genotypes. According to the BSC perspective, therefore, the financial standing of individuals with sensitive genotypes should be more dependent on parental income, perhaps the most formative aspect of environment.

In the process of investigating whether parental income moderates the relationship between genes and financial standing, this paper also addresses a new question related to intergenerational mobility: Why do some children follow in their parents' financial footsteps, reproducing inequality between generations, while others experience greater mobility? At the individual level, relatively little research has documented what factors increase or decrease the likelihood of economic mobility or why some individuals in a similar context experience socioeconomic mobility while others do not. If the biological sensitivity to context model extends to financial standing, then perhaps sensitive genotypes help explain why some individuals experience mobility while others in the same context do not. According to the BSC model, individuals with more copies of the sensitive genetic variants should be more dependent on parental income. In that case, carrying more sensitive genotypes could reduce intergenerational mobility. In contrast, individuals with fewer copies of sensitive genotypes (more stable variants) could enjoy less dependence on social background and greater opportunity 
for mobility. In other words, the likelihood of experiencing intergenerational mobility could partly depend on genotype - not because genotypes are inherently positive or negative, but because they relate to environmental sensitivity.

Growing evidence supports the hypothesis that certain genotypes may increase sensitivity to context rather than just risk (Belsky et al. 2013; Belsky et al. 2009; Bakermans-Kranenburg and Ijzendoorn 2007; Belsky et al. 2007). The implications of this model for intergenerational inequality, however, have yet to be investigated directly. A difficulty of conducting both genetic and social research is that genotype and social environment are not randomly distributed throughout the population. To address this difficulty, I use sibling comparisons to investigate this hypothesized relationship between genotype and intergenerational mobility. Full siblings share their parents, so parental characteristics are the same. In addition, within full sibling pairs each sibling has an equal chance of inheriting one of two alleles (genetic variants) at a particular genetic location from each parent (Fletcher and Lehrer 2011). Thus, genotype is randomly distributed within full sibling pairs. Capitalizing on these methodological advantages of siblings, and using a genetic index previously found to increase sensitivity (Belsky and Beaver 2011), I use family fixed effects models of sibling data from the National Longitudinal Survey of Adolescent Health (Add Health; Harris 2009) to investigate whether an index of sensitive genotypes moderates parent-child economic similarity.

In the following sections, I review literature on gene-environment interaction research, intergenerational mobility, and the relationship between genes, environment, and financial standing. I then provide details about data and methods, followed by results and a conclusion including limitations and implications. 


\section{Gene-Environment Interaction}

Over the last decade, research has found evidence of gene-environment interactions, suggesting genetic effects on a variety of measures (e.g., depression, college attendance) depend on our environment (Caspi et al. 2003; Guo et al. 2008; Shanahan et al. 2008). More recently, the BSC hypothesis (Ellis and Boyce 2008; Boyce and Ellis 2005) or differential susceptibility model (Belsky 2013, 2005) suggests certain genotypes make individuals more sensitive to environment. Rather than the idea that certain "risky" genotypes simply yield more negative outcomes, or more negative average outcomes in disadvantaged environments (traditional geneenvironment interaction perspective), the sensitivity argument suggests these genotypes increase variation in outcomes depending on environment. Subjected to a growing body of research (Conley et al. 2013; Belsky et al. 2013; Pluess et al. 2010; Pluess et al. 2011; Simons et al. 2011; Bakermans-Kranenburg and Ijzendoorn 2007; Belsky et al. 2007; Pluess and Belsky 2010), the differential susceptibility model suggests that in a deprived environment, those with a sensitive genotype could experience more negative outcomes, but in a particularly supportive environment they could achieve even more positive outcomes than those with the more stable, alternative genotype. Thus, individuals with more sensitive alleles could experience more negative, but also more positive, outcomes than others depending on environmental conditions.

Despite enjoying growing research attention, efforts to understand gene-environment interaction - and to test the differential susceptibility model - face two central limitations. Methodologically, GxE research struggles to address the non-random distribution of both environment and genotype. As noted by Conley and Rauscher (2013), most existing research relies on environmental measures (e.g., parental maltreatment, family dinners, or peer characteristics) that could be associated with genotype (Caspi et al. 2002, 2003; Guo et al. 2008; 
Pescosolido et al. 2008; Shanahan et al. 2008; Daw et al. 2013). For example, it is possible that the likelihood of frequent family dinners or parental maltreatment is associated with parental genetic characteristics. In that case, the interactions found by Guo et al. (2008) and Caspi et al. (2002) would reflect genetic interaction with unmeasured parental genotype. Similarly, research finds evidence that genotype is correlated within friendship networks (Fowler et al. 2011), suggesting individuals select into peer groups (and possibly other social environments) partly on the basis of genotype. In that case, evidence of an interaction between peer characteristics and genotype (Dick et al. 2007; Daw et al. 2013) could partially reflect gene-gene interactions rather than a gene-environment interaction. Although some GxE research carefully addresses nonrandom environmental variation (e.g., Bakermans-Kranenburg et al. 2008; Fletcher and Lehrer 2011), additional research taking methodological steps to address this issue is required to advance understanding.

In addition to environment, however, GxE research must also address the possibility that genotype is not randomly distributed. Population stratification occurs when genetic variation is not randomly distributed and is correlated with environmental or genetic differences. For example, Thomas and Witte (2002:505) note that dopamine receptor D2 (DRD2) genotype is not equally distributed by ethnicity. Therefore, any apparent effects of DRD2 variation may actually be reflecting the social dynamics of ethnicity and not the causal effect of the DRD2 allele. Similarly, evidence of an interaction between DRD2 genotype and environmental factors (e.g., Shanahan et al. 2008) could reflect population stratification rather than a gene-environment interaction. Others (Gelernter and Kranzler 1999; Abdolmaleky et al. 2004; Fan and Sklar 2005; Sabol et al. 1998) show significantly different ethnic distributions of DRD2, serotonin transporter (5-HTT), and monoamine oxidase A (MAOA) genotypes, which are frequently 
investigated in gene-environment interaction research. While it is possible to control for ethnicity, it is impossible to know all of the relevant characteristics to control for and without some method of randomization we cannot know whether a given allele is orthogonal to all social environments. Coupled with evidence that individuals self-select into social environments based on genotype (Fowler et al. 2011), we must conclude that analyses failing to account for the nonrandom distribution of genotype may be biased.

Methodologically, therefore, gene-environment interaction research must continue efforts to address the non-random distribution of both genotype and environment. Within-family analyses, including sibling comparisons, offer one methodological opportunity to address these challenges (Fletcher and Lehrer 2011). Because full siblings share an equal chance of inheriting one of two alleles at each genetic locus from each parent, genotype is randomly distributed within full siblings. In addition, siblings share much of their environment, including the same parents, which holds constant a great deal of environmental variation.

Beyond methodological challenges, however, GxE research must also investigate broader implications of the differential susceptibility model. For example, while sensitive genotypes are often described as "plastic" in the differential susceptibility model (Belsky and Pluess 2009; Belsky et al. 2009; Barker 2005), what does plastic entail? The term plastic suggests a high degree of malleability. In materials science, however, plasticity indicates a substance that can be shaped under pressure, but retains its new shape once the pressure is removed. A paper clip, for example, can be bent out of shape, but it retains that new shape after the pressure stops. In contrast, elastic materials, such as rubber bands, can be bent or shaped under pressure but return to their original shape after the pressure is removed. 
If we extend this plastic analogy, then perhaps sensitive alleles are associated with greater dependence on environment, but also less mobility. That is, individuals with more sensitive alleles may be more dependent on parental characteristics or social background and enjoy less opportunity for intergenerational mobility. Thompson (2014), for example, finds a pattern consistent with this for education, but only among men with a particular variant of the MAOA gene. In this study, I investigate the relationship between sensitive alleles and intergenerational mobility, while taking methodological steps to address the non-random distribution of genotype and environment.

\section{Intergenerational Mobility}

How is inequality transmitted between generations? Simple genetic explanations suggest economic standing is inherited at birth and is therefore not amenable to policy changes (Clark 2014; Herrnstein and Murray 1994). These genetic explanations suggest that the importance of genotype for adult economic outcomes should be unrelated to economic background. That is, if genetics simplistically determine adult financial standing, they should play the same role for everyone, regardless of the context in which one was raised.

Existing research raises considerable doubt about these simplistic genetic perspectives. We know, for example, that intergenerational mobility varies across multiple dimensions, including nation (Ermisch et al. 2012; Breen 2004; Solon 2002; Erikson and Goldthorpe 1992; DiPrete and Grusky 1990), time (Breen 2004), regional differences such as local tax expenditures (Chetty et al. 2013, 2014), occupational category (Erikson and Goldthorpe 1992; Featherman and Hauser 1978), level of education (Torche 2011; Breen and Jonsson 2005; Hout 
1988), and measure, including economic, educational, cognitive, and behavioral characteristics (Ermisch et al. 2012; Duncan et al. 2005).

Intergenerational similarity clearly depends on social context. Yet, perhaps because intergenerational mobility is a population characteristic, less is known about why some individuals in a similar context experience socioeconomic mobility while others do not. Similar to studies of mobility, research on resilience (Seccombe 2002; Garmezy 1987; Werner 1993; Wexler et al. 2009) often identifies family- or community-level factors associated with greater likelihood of resilience despite disadvantaged contexts. Yet siblings who were raised in the same family and community can experience varying levels of socioeconomic attainment and intergenerational mobility. Research on individual resilience often examines developmental or psychological outcomes (Howell and Miller-Graff 2014; Lowe et al. 2015; Kassis et al. 2013), with less examination of socioeconomic attainment. At the individual level, relatively little research has documented factors that increase or decrease the likelihood of economic mobility.

In an effort to better understand individual-level factors associated with mobility, this study investigates the relationship between sensitive alleles and intergenerational mobility among siblings, who share much of their environment. In the process, by investigating the differential susceptibility model, this project allows for a more complex relationship between genes and intergenerational transmission than generally construed. Rather than a mediating role alone, as suggested by Clark (2014), I investigate both a mediating and moderating role of specific genotypes in intergenerational economic transmission.

\section{Genetic Sensitivity, Environment, and Financial Outcomes}


Research has identified multiple sensitive genetic variants, which could increase sensitivity to parental financial standing. For example, Taylor et al. (2006) find that short 5-HTT alleles increase sensitivity to early childrearing history and recent life events. Similarly, Retz et al. (2008) find increased sensitivity to childhood environment among those with short 5-HTT alleles. Daw et al. (2013) find evidence that individuals with more short 5-HTT alleles are more sensitive to peer behaviors. These studies examine different contexts and outcomes, including depression (Taylor et al. 2006), ADHD (Retz et al. 2008), and binge drinking (Daw et al. 2013), suggesting that the short 5-HTT alleles increase sensitivity to environment in general terms across multiple outcomes.

There is similar evidence for the DRD4 7-repeat allele. Individuals with more copies of the 7-repeat DRD4 allele are more sensitive to maternal sensitivity and parenting quality (Bakermans-Kranenburg and van IJzendoorn 2006; Sheese et al. 2007), even when an experimental intervention is used to impact parenting quality (Bakermans-Kranenburg et al. 2008).

In the case of DAT1, Laucht et al. (2007) found that those carrying the 10-repeat allele are more sensitive to psychosocial adversity than others. Mitchell et al. (2014) found evidence that the DAT1 10-repeat allele, in combination with others, increased sensitivity to family socioeconomic status. Similarly for DRD2, evidence suggests the A1 allele increases sensitivity to maternal sensitivity (Mills-Koonce et al. 2007; Propper et al. 2008) and birth weight (Keltikangas-Jarvinen et al. 2007).

Finally, the 2- and 3-repeat MAOA alleles also show evidence of increasing sensitivity to context. Kim-Cohen et al. (2006) find evidence that these alleles increase sensitivity to physical abuse when predicting mental health and ADHD symptoms. Research similarly finds evidence 
that the short MAOA alleles increase sensitivity to childhood adversity (Foley et al. 2004) and maltreatment experience (Nilsson et al. 2006). In a paper particularly relevant for this study, Thompson (2014) documents that males with a short MAOA allele are more sensitive to parental income and education.

Most of the above studies investigate one genotype at a time. Consistent with the idea that these alleles all similarly increase sensitivity to context, it is becoming increasingly common to create a polygenic or additive index of sensitive alleles (Mitchell et al. 2014; Pearson-Fuhrhop et al. 2013; Stice et al. 2012). Belsky and Beaver (2011), for example, create a cumulative index of the five alleles discussed above and find that the index increases sensitivity to parenting. To build on their analysis, I use the same index in this study.

As illustrated in the review above, genetic sensitivity analyses have investigated a variety of environmental contexts and outcomes, including self-regulation (Belsky and Beaver 2011), sensation seeking (Sheese et al. 2007), and ADHD (Retz et al. 2008). The broad array of outcomes and contexts suggests that the genotypes in question increase sensitivity broadly. That is, the evidence suggests they make multiple individual outcomes more sensitive to the environment one experiences.

Research is investigating a growing number of outcomes, but very little genetic sensitivity research investigates financial outcomes. A growing body of GxE interaction research examines effects on educational outcomes (Thompson 2014; Conley and Rauscher 2013; Shanahan et al. 2008; Keltikangas-Jarvinen et al. 2007), which have implications for income and earnings. In a related study, Cook and Fletcher (2015) use data from the Wisconsin Longitudinal Study (WLS) and sibling fixed effects to investigate gene-environment interaction in relation to cognition (IQ). 
Although education and cognition may be more directly related to income than other outcomes investigated by GxE research, thus far I have been able to find only one study that directly examines gene-environment interaction effects on financial outcomes. In addition to studying whether an index of neuroplasticity genotypes moderate the relationship between birth weight and IQ, Cook and Fletcher (2015) also examine the genotype-birth weight interaction for adult wages. For both IQ and wages, and even when including sibling fixed effects, Cook and Fletcher find that an index of three genotypes moderates the effect of birth weight (a measure of environment before birth). There is some evidence, therefore, that financial outcomes may depend on an interaction between genes and environment.

Despite their careful methodological approach, Cook and Fletcher (2015) note that birth weight it not randomly distributed within sibling pairs and could differ with respect to genotype, among other things. Furthermore, birth weight is only one potential environmental factor that may moderate the relationship between genes and financial outcomes. Using a similar approach, including sibling fixed effects and data from the National Longitudinal Study of Adolescent to Adult Health (Add Health) supplemented by WLS data, this study investigates whether the relationship between childhood financial standing (i.e. parental household income during childhood, which is the same within sibling pairs) and young adult financial standing varies by an index of sensitive alleles. In the process, this study investigates whether intergenerational economic mobility varies by genotype within sibling pairs. By combining two areas of inquiry, which until now have remained largely distinct, I extend research on both GxE and intergenerational mobility to pose the hypothesis below.

\section{Hypothesis}


Under the differential susceptibility model (or the BSC hypothesis), individuals with fewer sensitive alleles should demonstrate weaker association with parental measures of financial standing (higher mobility) than those with more contextually sensitive alleles. Individuals with more sensitive alleles should be more sensitive to parental financial standing, yielding a greater range in outcomes and stronger association with parental socioeconomic measures (lower mobility).

\section{Methods and Analysis}

The following sections provide details about the data, measures, and analyses used in this study.

Data

The National Longitudinal Study of Adolescent to Adult Health (Add Health) follows a nationally representative sample of U.S. adolescents who were in grades 7-12 in 1994-5. Revisiting over 15,000 youth in 1996, 2001-2, and 2007-8, Add Health provides a wealth of information on adolescent development, health, academic achievement, and economic standing. Most important for this analysis, Add Health includes information about parents, siblings, and genes. In particular, the Adolescent Pairs Data allow detailed comparisons of 3,139 pairs of twins, singleton siblings, half siblings, step siblings, or unrelated youth who lived in the same household. Full siblings are the focus of the main analysis because full siblings share an equal chance of inheriting one of two alleles at each genetic locus from each parent. Therefore, within full siblings, genotype is randomly distributed. Although sibling comparisons maximize internal validity and provide the preferred method here, results from the full sample are also provided to 
illustrate the importance of accounting for the non-random distribution of genes and environment in the population.

The Wave IV DNA Data file provides information about variation at multiple genetic locations among approximately $96 \%$ of the 15,701 Wave IV respondents. Of particular interest for this analysis is the genotype information for DAT1, DRD2, DRD4, MAOA, and 5-HTT genes, which previous research identifies as having a sensitive (or plastic) genetic variant (Belsky and Pluess 2009; Belsky and Beaver 2011). Given its longitudinal nature, Add Health also allows comparison of individual and parental financial standing. Child financial outcomes are measured in Wave IV, when children were ages 24 to 34, with an average age of about 29. Therefore, results represent effects for young adults rather than when individuals have reached their peak earning potential.

Within-sibling analyses limit the sample available, which may raise questions about generalizability. I therefore conduct supplementary analyses using data from the Wisconsin Longitudinal Study (WLS), which represents the Wisconsin high school graduating class of 1957. Multiple waves of data have been collected about 10,317 graduates as well as one randomly selected sibling of each graduate. In addition to longitudinal information on financial standing, genotype information for an array of single nucleotide polymorphisms (SNPs; genetic locations that vary within the human population) was collected for participating individuals and their siblings. The WLS analysis is supplementary, because little research has been done about whether the SNPs collected increase sensitivity to the environment. Discussion of the methods and results based on the WLS data are provided in the Appendix.

\section{Measures}


Parental financial standing is based on Wave I data, when the children were adolescents. Parental financial standing is measured using total household income and percent of the federal poverty level (FPL). Total household income includes income from all individuals in the household and is used as the primary measure in analyses because it offers a widely understood indicator of overall financial standing and a consistent measure for both parents and children. Results, however, are similar using parental percent of the FPL. One potential concern for the sibling analysis is that parental financial standing is measured at different ages for siblings. That is, parental financial standing may change over time and could differ if measured at the same age for each sibling. I partially address this by controlling for age. However, it is important to note that parental financial standing is measured with error due to the single-year measure.

Child financial standing as a young adult is based on Wave IV data, when children were ages 24 to 34, with an average of about 29. Child financial standing is measured using total household income, percent of the FPL, individual earnings, and total household net worth (assets minus debts). Total household income is measured categorically (with 12 categories) in Wave IV. This is not ideal, because it reduces variation. However, earnings and net worth measures provide alternative continuous measures with greater variation. For total household income, I take the midpoint of each category and $\$ 15,000$ above the cutoff for the highest category, which includes households with income $\$ 150,000$ or above.

Nearly all Wave I interviews took place in 1995 and $98 \%$ of Wave IV interviews took place in 2008. Income questions asked about total income in the last year. Therefore, parental income from Wave I measures 1994 household income and is converted to 2007 dollars (the income year recorded in Wave IV) using the Bureau of Labor Statistics Consumer Price Index 
Inflation Calculator. ${ }^{1}$ Percent of the FPL is total household income divided by the appropriate federal poverty threshold for the total number of people in the household. Poverty thresholds are based on 1994 U.S. Census Bureau Poverty Guidelines for parent measures and on 2007 Health and Human Services Poverty Guidelines for child adult measures. ${ }^{2}$

Parental household income and child financial outcome measures are skewed (particularly earnings and net worth). I therefore conduct regression analyses using transformed versions, which provide a more normal distribution. The log transformation does not reduce (and in nearly all cases increases) the absolute value of the skewness for both parent and child measures. The square root transformation reduces skewness and provides a more normal distribution of the data better than the log transformation. I therefore use the square root transformation for household income and individual earnings measures. In the case of household net worth, the inverse hyperbolic sine (IHS) transformation best reduces the skew while retaining information for those with negative net worth values. I therefore use the IHS transformation for household net worth. Results, however, are similar using the square root transformation for consistency. To ease interpretation and because it is not highly skewed, I do not transform percent of FPL, but results using a square root transformation of this measure are similar. Genetic sensitivity score is the same as that used in Belsky and Beaver (2011) and is calculated as the sum of the total number of sensitive alleles at polymorphisms of the DAT1, DRD2, DRD4, MAOA, and 5-HTT genes. Existing research has identified a variant at each of these polymorphisms as a sensitive (also called plastic) allele that increases sensitivity to environmental context (Belsky and Pluess 2009; Belsky and Beaver 2011). Specifically, these

\footnotetext{
${ }^{1}$ http://data.bls.gov/cgi-bin/cpicalc.pl

${ }^{2} 1994$ www.census.gov/hhes/www/poverty/data/threshld/thresh94.html; 2007 http://aspe.hhs.gov/poverty/07poverty.shtml
} 
alleles include: the long (10-repeat) DAT1 allele; the long (7-repeat) DRD4 allele; the short (2or 3-repeat) MAOA variable number tandem repeat allele; the short 5-HTT allele (14 repeats); and the DRD2 A1 (or T) allele. I create alternative genetic sensitivity scores, including slightly different alleles (with alternative numbers of repeats) and including alleles at additional genetic locations with less evidence of sensitivity. Results are similar and are shown in Appendix Table S3, Panels A-E.

The polymorphisms included are related to the processing of neurotransmitters that play an important role in a variety of behaviors related to economic standing (e.g., attention, aggression, depression) (Pearson-Fuhrhop et al. 2014; McDermott et al. 2009; Cummins et al. 2012). Furthermore, experimental research suggests variation at these genes is associated with financial decision making (e.g., Carpenter et al. 2011; Dreber et al. 2009; Zhong et al. 2009a, 2009b; see Appendix for more details). Because individual alleles are not likely to have strong enough effects on complex outcomes for statistical detection (Pearson-Fuhrhop et al. 2014) and to conform to the increasingly common practice of using polygenic or additive genetic measures (Mitchell et al. 2014; Pearson-Fuhrhop et al. 2013; Stice et al. 2012; Belsky and Beaver 2011), I create a genetic sensitivity score by summing all of the sensitive alleles held by an individual. Throughout the paper, I refer to this measure as genetic sensitivity score (GSS), but an alternative term is cumulative genetic plasticity score (Belsky and Beaver 2011).

As a sensitivity analysis to check for a potential interactive relationship among the alleles, I also create a genetic interaction sensitivity score, which interacts the number of sensitive alleles at each of the genetic locations included in the GSS. Thus, the genetic interaction score is an interaction of the number of long DAT1 alleles, long DRD4 alleles, short 
MAOA alleles, short 5-HTT alleles, and DRD2 A1 alleles each individual carries. These results are provided in Appendix Table S4.

\section{Analysis}

To assess whether intergenerational mobility and sensitivity to context differ by genotype, I compare the strength of parent-child economic similarity by genetic sensitivity score. First, I conduct analyses using the whole Add Health sample (including those with and without siblings), adjusting the standard errors for family level clustering. The full sample models are run twice, controlling only for gender and age and then with extensive controls. However, parental characteristics and genotype are not randomly distributed in the general population and, even with extensive controls, the full sample may yield biased estimates.

To provide a more rigorous estimate, my second and preferred analysis examines the same relationship within same sex full sibling pairs. Because each sibling has an equal chance of inheriting one of two alleles at each genetic locus from each parent, genotype within full sibling pairs is random (Fletcher and Lehrer 2011). Furthermore, sibling pairs hold constant much environmental variation. Importantly for this analysis, parental income is the same for sibling pairs. Other environmental variation is subsequent to the genes one inherits.

Some GxE research uses twin comparisons to address potentially important environmental differences experienced by singleton siblings (e.g., Conley and Rauscher 2013). However, twin comparisons face their own limitations, particularly in relation to external validity. For example, twins must split parental attention and resources, particularly during crucial early years of development. Parents may treat twins differently than singleton children, emphasizing their similarities or differences or simply providing them less attention due to stress and fatigue. I aim to balance internal and external validity by examining same sex singleton 
sibling pairs, which offer more generalizability than twins but greater internal validity than a sample of non-siblings. Therefore, in the preferred analysis I limit the Add Health sample to same sex singleton full sibling pairs with complete information for parents and both siblings. Some families have more than one sibling pair represented in the Add Health data. In those instances, I randomly select one sibling pair per family and exclude the others to ensure that certain families are not over-represented.

Using this sample of same sex singleton full siblings, I provide descriptive information on sibling differences and conduct family fixed effects regressions to adjust for between-family differences in child outcomes or genotype. A potential concern of sibling comparisons is that parental assortative mating could reduce genetic variance within families and reduce the power of an analysis. If the sibling correlation of genetic sensitivity scores was higher than 0.50 , it would suggest assortative mating. However, in the sample of siblings used here, the sibling correlation of genetic sensitivity scores is 0.49 , which reduces concern about potential assortative mating.

In the full sample, I regress child financial outcome on genetic sensitivity score, parental income, and genetic sensitivity score interacted with parental income, controlling for age and sex and then adding additional controls measured during adolescence including household size, Aid to Families with Dependent Children receipt, food stamp receipt, having enough money for bills, birth weight, special education status, cognitive disability status, and several parental measures, including parental education, self-rated health, alcohol use, smoking, age, employment, marital status, race, ethnicity, and seatbelt use.

In the sibling sample, as shown in Equation 1 below, I regress child financial outcome on genetic sensitivity score and genetic sensitivity score interacted with parental income, controlling 
for age and including family fixed effects $\left(\eta_{j}\right)$. Parental income and sex are the same for both siblings, so the main effects drop out of the model. In both samples, standard errors are robust to heteroscedasticity and adjusted for family level clustering. The full sample is weighted to represent the population.

$$
\text { Child Income }_{i j}=\alpha_{0}+\beta_{1} \mathrm{GSS}_{i j}+\beta_{2} \mathrm{GSS}_{i j} * \text { Parent Income } j+\beta_{3} \text { Age }+\eta_{j}+\varepsilon_{i j}
$$

The coefficient of primary interest is $\beta_{2}$, which estimates whether parent-child economic association differs by individual genetic sensitivity score. Under the BSC hypothesis, siblings with fewer sensitive alleles should demonstrate weaker association with parental measures than their sibling with more contextually sensitive alleles. Siblings with more sensitive alleles should be more sensitive to parental SES, yielding a greater range in outcomes and stronger association with parental SES measures. Therefore, within same-sex sibling pairs, $\beta_{2}$ should be positive.

To assess robustness of the findings, the main analyses include multiple measures of child financial standing as a young adult, including household income, percent of the federal poverty level, individual earnings, and net worth. Sensitivity analyses using alternative genetic sensitivity score calculations (i.e. including alternative alleles, such as the MAOA 2-, 3-, and 5repeat alleles, the DRD4 6- through 10-repeat alleles, or DAT 10- through 13-repeat alleles) or controlling for age squared yield similar results. I also conduct sensitivity analyses controlling for birth weight, birth order, and parental favoritism and using parental education and percent of FPL instead of income. Results are similar using these approaches and are provided in Appendix Tables S5 and S6.

To further assess robustness or range of reaction, I conduct family fixed effects regressions separately among high and low income families. These results are presented below 
and are consistent with the main analyses. As a final robustness check, I conduct family fixed effects regressions separately among white and black sibling pairs. These results are presented in Appendix Table S7.

\section{Results}

Descriptive Statistics

Descriptive information for the sample of same sex singleton siblings is presented in

Table 1. Mean values are presented for all siblings, but also separately for siblings from households above and below the median value of parental household income $(\$ 56,000$ in 2007 dollars). Descriptive information for the full sample is provided in Appendix Table S1.

[Tables 1 and 2 about here]

As Table 1 shows, after adjusting for inflation, mean parent and child household incomes are comparable, with parent income approximately $\$ 3,300$ higher than child income. This difference could reflect the relatively young age at which child household income is measured (mean 29 years, 12 years younger than mean parent age). Although mean parental income differs drastically among those above and below the median household income (a gap of approximately $\$ 70,300$ ), the difference is much smaller in the next generation (approximately $\$ 18,600)$. This suggests, on average, that children experienced mobility toward the mean upward among those from low income backgrounds and downward among those from high income backgrounds.

The family fixed effects analysis relies on sibling differences in sensitive alleles. The regression results therefore rely on sibling pairs with discordant genetic sensitivity scores. Table 2 shows the frequency distribution of individuals in the sibling sample by the absolute value of the pair difference in GSS. This table shows that approximately $30 \%$ of the sibling sample does 
not differ in GSS. Sibling pairs with different GSS scores typically have one or two different alleles. One potential concern in the fixed effects regressions is that if the parental characteristics of concordant siblings differ from those of discordant siblings, the generalizability of results could be limited. Appendix Table S2 provides descriptive information on a variety of measures for sibling pairs with concordant and discordant GSS values. Importantly, the difference in means between discordant and concordant sibling pairs is not significant for any of these measures, including young adult and parental measures. Although these descriptive comparisons are not conclusive, they suggest results are generalizable to all singleton siblings, rather than just those who differ in genetic sensitivity score.

To provide within-family descriptive information, I calculate sibling differences in financial outcomes. Within each sibling pair, these differences represent the financial outcome value (e.g., young adult household income) for the sibling with the higher GSS minus the value for the sibling with the lower GSS. Siblings with the same GSS are excluded from this descriptive analysis. Because individuals with more sensitive alleles are expected to fare worse in disadvantaged environments and better in supportive environments, the differential susceptibility model predicts significant negative differences among low income families, but significant positive differences among high income families.

Mean sibling differences by parental household income are presented in Table 3. For each financial outcome measure, mean sibling difference is negative among low income households and positive among high income households. For all of the measures, the difference between low and high income households is significant $(\mathrm{p}<0.05)$. Figure 1 illustrates these differences and shows that sibling difference is positive and significantly different from zero among high income households for household income and percent of the federal poverty level. 
Among low income households, sibling difference significantly differs from zero in the negative direction for all measures except household net worth.

[Table 3 and Figure 1 about here]

These mean differences are consistent with the differential susceptibility model. The sibling with higher GSS tends to have lower financial outcomes in low income families, but higher financial outcomes in high income families. These differences, however, do not hold for household net worth.

\section{Regression Analyses}

Regression results for the full sample (including those without a sibling in the data) are

presented in Table 4. Models 1-4 include minimal controls (age and gender); Models 5-8 include multiple controls. In nearly all models, neither GSS nor its interaction with parental household income is significantly related to child financial outcomes. In Model 7, however, which includes a broad array of controls, GSS is negatively related to earnings and its interaction with parental income is positively related to earnings. These coefficients are only marginally significant $(\mathrm{p}<0.10)$, but they suggest that the precision of the estimate increased with additional controls. The null finding in most models could be because there is no relationship, but could also reflect biased estimates due to the non-random distribution of genes and environment in the full sample.

[Tables 4 and 5 about here]

Table 5 shows results of models limited to the sibling sample and including family fixed effects, which provide more rigorous estimates that address potential between-family biases in Table 4. The main effect of GSS is negative, but the interaction between GSS and parental household income is positive and significantly different from zero when predicting income, percent of FPL, and earnings (i.e. all outcome measures except household net worth). Siblings 
with a higher GSS tend to have lower financial outcomes than their sibling with a lower GSS, but only in families from low income backgrounds. In each case except net worth, the predicted financial outcome for those with a higher GSS is higher among high income families. In Model 1, for example, each additional sensitive allele is associated with a higher adult household income when parental household income is approximately $\$ 70,000$ or higher. In Model 2 , the crossover point is approximately $\$ 50,000$, and in Model 3 it is approximately $\$ 55,000$. These transition points are generally centered around the overall mean $(\$ 67,000$ in 2007 dollars) and the median $(\$ 56,000)$ of parental household income.

Figure 2 illustrates the relationship between parent and child household income by number of sensitive alleles. The figure clearly illustrates that, compared to their same sex sibling with fewer sensitive alleles, a sibling with more sensitive alleles tends to have lower household income in young adulthood if raised in a low income household, but higher household income if raised in a high income household. For those with parental income near zero, each additional sensitive allele results in approximately $\$ 1,500$ less in annual household income. For siblings with parental income near $\$ 150,000$, in contrast, each additional sensitive allele is estimated to result in approximately $\$ 375$ in additional annual household income.

This pattern is similar when predicting percent of FPL and individual earnings. For those with parental income near zero, each additional sensitive allele is estimated to reduce one's standing on the federal poverty scale by 75 percentage points. For those whose parental household income was $\$ 150,000$, each additional sensitive allele is estimated to increase one's standing by 60 percentage points. Those with parental income near zero are estimated to earn approximately $\$ 1,100$ less per year for each additional sensitive allele, while those with parental 
income of $\$ 150,000$ are estimated to earn an additional $\$ 500$ per year for each additional sensitive allele.

[Figure 2 about here]

The null result for household net worth is intriguing. Net worth could be more strongly determined by factors beyond individual differences, such as parental net worth or financial bequests, than household income or individual earnings (see e.g., Black et al. 2015). The alleles included in the GSS have been implicated in behaviors (e.g., attention, aggression, depression) associated with labor market outcomes (Pearson-Fuhrhop et al. 2014; McDermott et al. 2009; Cummins et al. 2012). It is possible, therefore, that the increased sensitivity to context works through behaviors. In low income contexts, the sensitive alleles could encourage behaviors associated with lower earnings and income. In high income contexts, the same alleles could encourage behaviors associated with higher earnings and income. In such a scenario, these alleles could moderate labor market outcomes such as income and earnings, but remain largely unrelated to net worth. Results are consistent with this pattern, but explaining the different results for net worth are beyond the scope of this paper.

\section{Sensitivity Analyses}

The above results suggest the relationship between genetic sensitivity score and individual financial outcomes should differ depending on parental financial standing as an adolescent. As a robustness check of this interaction, I fit separate regressions limited to sibling pairs from high and low income households. According to the differential susceptibility model, the main GSS effect should be negative among low income households and positive among high income households. Results from Table 5 suggest the crossover point is generally around median parental income. Table 6 compares GSS coefficients from family fixed effects 
regressions among siblings from high and low income families. The top group of coefficients in Table 6 is from models limited to those above and below median parental household income (\$56,000 in 2007 dollars). However, to examine cutoffs farther from the median, such as the crossover point found in the fixed effects model predicting household income, I also compare results among sibling pairs from households above the $65^{\text {th }}$ and $75^{\text {th }}$ percentiles $(\$ 70,000$ and $\$ 81,000)$ and below the $35^{\text {th }}$ and $25^{\text {th }}$ percentiles $(\$ 39,000$ and $\$ 34,000)$. The regression model is the same as that presented in the main analyses, but excludes the interaction term between GSS and parental household income.

\section{[Table 6 about here]}

Results in Table 6 show that among low income households, the GSS coefficient is negative in all models (except those predicting net worth) and statistically different from zero in all models predicting household income $(\mathrm{p}<0.05)$. The GSS coefficient also reaches marginal significance $(\mathrm{p}<0.10)$ when predicting earnings below the $35^{\text {th }}$ income percentile and when predicting percent FPL below the $25^{\text {th }}$ percentile. Among high income households, the GSS coefficient is positive in every model (except two of those predicting net worth) and statistically different from zero in all models predicting percent of federal poverty level $(\mathrm{p}<0.01)$. The positive GSS coefficient also reaches significance in a few other models: predicting earnings above the $65^{\text {th }}$ percentile $(\mathrm{p}<0.05)$ and above the $75^{\text {th }}$ percentile $\mathrm{p}<0.10$ ); predicting household income above the $75^{\text {th }}$ percentile $(\mathrm{p}<0.01)$ and above the median $(\mathrm{p}<0.10)$. Overall, the results shown in Table 6 further support the differential susceptibility model. As in the main analyses, a higher GSS is associated with lower financial outcomes among those from low income households, but higher financial outcomes among those from high income households. 
In terms of intergenerational mobility, the above results suggest that individuals with a high GSS experience less financial mobility; that is, they have financial outcomes more similar to their parents than their siblings with fewer sensitive alleles. The positive interaction terms (in Table 5) between GSS and parental financial standing imply that each sensitive allele provides a greater return on parental financial standing. GSS therefore confers both greater sensitivity to adolescent financial context and less financial mobility. This positive relationship between GSS and intergenerational financial similarity is illustrated in Figure 3.

[Figure 3 about here]

Solon (1992) estimated that intergenerational income elasticity (individual income return to parental income) in the U.S. is at least 0.40 . This suggests that if a child's parental income was $\$ 20,000$ less than the mean, the predicted child income would be $\$ 8,000$ (or $40 \%$ of that difference) less than the child mean. Based on Model 1 in Table 5, each additional sensitive allele is estimated to increase intergenerational income elasticity by 0.11 . Thus, if an individual's parents earned $\$ 20,000$ less than the parental mean, then for each additional sensitive allele, a child's predicted income would be an additional \$2,200 less than the child mean. Income in this study is measured with considerably more bias than the multi-year measures Solon uses. Furthermore, I use a square root rather than a log transformation. To the extent results are comparable, however, each additional sensitive allele is estimated to confer an additional $25 \%$ of Solon's estimated overall intergenerational income elasticity.

Sensitivity analyses using alternative genetic sensitivity score calculations yield similar results (presented in Appendix Table S3, Panels A-E). Results are also similar when controlling for age squared or weighting by average family weight to adjust for unequal likelihood of 
families appearing in the sample. In addition, results are consistent using parental education or percent of the federal poverty level instead of income (Appendix Tables S6).

Finally, results are not driven by white or black young adults alone; results for models predicting household income and percent FPL are similar when limited to either white or black sibling pairs (see Appendix Table S7). Interestingly, one difference is that the coefficient for the interaction between GSS and parental income is significant when predicting earnings among white but not black young adults. However, the opposite is true when predicting net worth. A higher GSS predicts greater net worth among black young adults from higher parental income backgrounds. The different findings for earnings and net worth between white and black young adults could suggest the interaction works through different mechanisms in these groups. For example, if discrimination limits the earning potential of young black people regardless of behaviors (Pager 2003), then GSS and its interaction may have limited potential to impact their individual earnings. Similarly, the net worth of white young adults may depend largely on parental financial assistance (Nam et al. 2015), whereas behaviors and health may play a larger role in predicting net worth among black young adults. These potential explanations are speculative at this point and require further research.

In a further attempt to understand the mechanisms involved, I use sibling fixed effects models to investigate whether GSS predicts several parenting measures or whether the GSSparenting relationship differs at low and high incomes. Specifically, I predict the following parent-child relationship measures: whether the child reported feeling close to their mother or father; whether the child reported that their mother or father cares; child-reported parental favoritism (a scale ranging from -2 indicating a child received a lot less love and attention from parents compared to their sibling, to 2 indicating she received a lot more); and an index of the 
number of activities each child reported participating in with both parents or with either parent in the past four weeks (shopping; playing a sport; attending a religious service or church-related event; going to a movie, play, museum, concert, or sports event; working on a school project; talking about dating or a party; talking about a personal problem; talking about school work or grades; or talking about other school topics). Using the same model as Table 6, with controls for age and parental income as well as family fixed effects, I find that GSS does not significantly predict any of the parent-child relationship measures whether including the full sibling sample or when limiting the sample to siblings above or below median parental income. The null results suggest that parents do not treat their children differently by GSS and that the parenting-GSS relationship does not differ by income. These analyses are neither exhaustive nor conclusive, but the results suggest that the interaction effects between GSS and parental income (found in Tables 5 and 6) do not reflect different treatment by parents. Instead, the interaction could reflect different treatment or interpretation of gene-related behaviors by teachers and other members of society depending on income; or it could reflect differences in the likelihood of certain incomerelated health conditions by genotype and environment. These are only two potential mechanisms, however, and conclusively identifying mechanisms is beyond the scope of this paper.

\section{Conclusion}

This study investigates the relationship between an index of sensitive genotypes and intergenerational mobility, while taking methodological steps to address the non-random distribution of genotype and environment. Expanding beyond the outcomes typically examined in gene-environment interaction research, this study examines financial outcomes, including 
household income, percent of the federal poverty level, individual earnings, and household net worth. Overall, results provide further support for the differential susceptibility model, which suggests that genetic variants previously considered to increase risk actually increase sensitivity to environmental context. Compared to their same sex sibling, individuals with more copies of the sensitive genotypes do worse in low income contexts but fare better in high income contexts. These results add to the growing body of evidence suggesting the genetic variants in question increase sensitivity to context rather than risk (Belsky and Pluess 2009).

Further, by examining financial outcomes, this study suggests the implications of sensitive alleles may extend further than previously thought. Beyond health and behavioral consequences, for example, results suggest young adult financial standing depends significantly on genotype as well as parental income. Importantly, results suggest the genotypes examined are not inherently positive or negative, but rather relate to environmental sensitivity, making some children more or less sensitive to their parents' income.

This study has a number of limitations. First, it does not identify the mechanisms involved in the GxE interaction. Health and behaviors that previous research finds are both sensitive to genotype and environment and are associated with financial standing offer potential mechanisms; for example, ADHD depends on genotype and environment (Retz et al. 2008) and has negative effects on income (Fletcher 2014). The potential mediating role of health and behaviors is partially supported here because results generally do not hold when predicting net worth, which may be more strongly determined by other factors (Black et al. 2015). Furthermore, models predicting parenting measures suggest the GxE interaction effects do not reflect different treatment by parents. Nevertheless, definitively identifying mechanisms is beyond the scope of this study and requires further research. 
Another potential limitation is that the analytical approach relies on the stable unit treatment value assumption (SUTVA). In this case, the assumption is that the genotype of one sibling does not impact the outcome of the other sibling. Unfortunately, sibling genotype partly proxies for parental genotype, which could influence individual outcomes. Partially mitigating this concern is the fact that parental genotype and financial standing are the same for each sibling. Therefore, although sibling genotype may act as a proxy for parental measures, within sibling pairs individual outcome should be stable. Nevertheless, ideally I would control for parental genotype, but it is unavailable in Add Health as well as most other data sets with financial standing and genetic information. Future research should investigate similar interaction effects when controlling for parental genotype or investigate how such interaction effects might change when relaxing the stable unit treatment value assumption.

Finally, family fixed effects regressions rely on siblings with different GSS scores. Therefore, if families with genetically concordant siblings differ from those with discordant siblings, the generalizability of the results could be limited. To address this concern, Appendix Table S2 compares genetically concordant and discordant sibling pairs along a wide variety of measures and finds no significant differences. Although descriptive comparisons are not conclusive, they suggest results are generalizable beyond genetically divergent siblings. Furthermore, although the sibling comparison methods may reduce external validity, they increase internal validity over much GxE research.

Regardless of generalizability, results have implications for research on geneenvironment interactions and intergenerational inequality. As typically used in GxE research, the term plastic suggests a high degree of malleability. In the context of intergenerational mobility, however, sensitivity or plasticity also entails greater dependence on social background. 
Individuals with more sensitive genotypes are more dependent on parental financial standing and enjoy less opportunity for intergenerational mobility. The positive interaction terms between GSS and parental income indicate sensitivity to context, but also a stronger relationship between parent and child financial standing (i.e. higher intergenerational elasticity and lower intergenerational mobility). Thus, plasticity entails sensitivity, but also less mobility.

Both recent and classic arguments suggest genes simply mediate the intergenerational transmission of inequality; that is, economic standing is inherited at birth and is therefore not amenable to policy changes (Clark 2014; Herrnstein and Murray 1994). These simple genetic explanations suggest the importance of genotype for adult economic outcomes should be unrelated to economic background. Results of this study contradict such arguments and suggest the implications of certain genotypes depend on context, promoting positive outcomes at high incomes and negative outcomes at low incomes. Furthermore, this analysis suggests that sensitive genotypes may moderate rather than simply mediate intergenerational transmission. In short, financial standing is not genetically determined and policies could improve opportunity. By raising the total income of households with children, for example, we could ensure that the effects of sensitive alleles are positive for all, rather than negative for some children. 


\section{References}

Abdolmaleky, Hamid Mostafavi, Stephen V. Faraone, Stephen J. Glatt, and Ming T. Tsuang. 2004. Meta-Analysis of Association between the T102C Polymorphism of the 5HT2A Receptor Gene and Schizophrenia. Schizophrenia Research 67(1):53-62.

Bakermans-Kranenburg, Marian J., and Marinus H. van IJzendoorn. 2007. "Research Review: genetic vulnerability or differential susceptibility in child development: the case of attachment." Journal of Child Psychology and Psychiatry and Allied Disciplines 48(12): 1160-1173.

Bakermans-Kranenburg, Marian J., and Marinus H. van IJzendoorn. 2006. "Gene-environment interaction of the dopamine D4 receptor (DRD4) and observed maternal insensitivity predicting externalizing behavior in preschoolers." Developmental Psychobiology 48: 406409.

Bakermans-Kranenburg, Marian J., Marinus H. van IJzendoorn, Femke T.A. Pijlman, Judi Mesman, and Femmie Juffer. 2008. "Experimental Evidence for Differential Susceptibility: Dopamine D4 Receptor Polymorphism (DRD4 VNTR) Moderates Intervention Effects on Toddlers' Externalizing Behavior in a Randomized Controlled Trial.” Developmental Psychology 44(1): 293-300.

Barker, David J.P. 2005. “The Developmental Origins of Insulin Resistance.” Hormone Research 64(suppl 3): 2-7.

Belsky, Jay. 2013. "Differential Susceptibility to Environmental Influences." International Journal of Child Care and Education Policy 7(2): 15-31.

Belsky, Jay. 2005. "Differential susceptibility to rearing influence: An evolutionary hypothesis and some evidence." In B. Ellis \& D. Bjorklund (Eds.), Origins of the social mind: Evolutionary psychology and child development (pp. 139-163). New York: Guilford.

Belsky, Jay and Kevin M. Beaver. 2011. Cumulative-Genetic Plasticity, Parenting and Adolescent Self-Regulation.” Journal of Child Psychology and Psychiatry 52(5): 619-626.

Belsky, Jay and Michael Pluess. 2009. "Beyond Diathesis-Stress: Differential Susceptibility to Environmental Influences." Psychological Bulletin 135(6): 885-908.

Belsky, Jay, Michael Pluess, and Keith F. Widaman. 2013. "Confirmatory and Competitive Evaluation of Alternative Gene-Environment Interaction Hypotheses." The Journal of Child Psychology and Psychiatry 54(10):1135-43.

Belsky, Jay, C. Jonassaint, M. Pluess, M. Stanton, B. Brummett, and R. Williams. 2009. "Vulnerability Genes or Plasticity Genes?" Molecular Psychiatry 14: 746-754.

Belsky, Jay, Marian J. Bakermans-Kranenburg, and Marinus H. van IJzendoorn. 2007. "For better and for worse: Differential Susceptibility to environmental influences." Current Directions in Psychological Science 16(6): 300-304.

Black, Sandra E., Paul J. Devereux, Petter Lundborg, and Kaveh Majlesi. 2015. "Poor Little Rich Kids? The Determinants of the Intergenerational Transmission of Wealth. NBER Working Paper No. W21409. Retrieved September 10, 2015 from http://papers.ssrn.com/sol3/papers.cfm?abstract_id=2636168.

Boyce, W.T. \& Ellis, B. 2005. "Biological sensitivity to context: I. An evolutionarydevelopmental theory of the origins and functions of stress reactivity." Development and Psychopathology 17: 271-301.

Breen, Richard (ed.). 2004. Social Mobility in Europe. Oxford: Oxford University Press. 
Breen, Richard and Jan O. Jonsson. 2005. "Inequality of Opportunity in Comparative Perspective: Recent Research on Educational Attainment and Social Mobility." Annual Review of Sociology 31: 223-243.

Brookes, K., Mill, J., Guindalini, C., et al. 2006. A common haplotype of the dopamine transporter gene associated with attention-deficit/hyperactivity disorder and interacting with maternal use of alcohol during pregnancy. Archives of General Psychiatry 63: 74-81.

Carpenter, Jeffrey P., Justin R. Garcia, and J. Koji Lum. 2011. "Dopamine Receptor Genes Predict Risk Preferences, Time Preferences, and Related Economic Choices." Journal of Risk Uncertainty 42: 233-61.

Caspi, Avshalom, Joseph McClay, Terrie E. Moffitt, Jonathan Mill, Judy Martin, Ian W. Craig, Alan Taylor, and Richie Poulton. 2002. "Role of Genotype in the Cycle of Violence in Maltreated Children." Science 297:851-54.

Caspi, Avshalom et al. 2003. "Influence of Life Stress on Depression: Moderation by a Polymorphism in the 5-HTT Gene." Science 301:386-89.

Caspi, Avshalom, Terrie Moffitt, and Mary Cannon et al. 2005. "Moderation of the Effect of Adolescent- Onset Cannabis Use on Adult Psychosis by a Functional Polymorphism in the Catechol- O- Methyltransferase Gene: Longitudinal Evidence of a Gene by Environment Interaction.” Biological Psychiatry 57(10):1117-27.

Cervilla, Jorge A., Margarita Rivera, Esther Molina, Francisco Torres-Gonzalez, Juan A. Bellon, Berta Moreno, Juan de Dios Luna, Jose A. Lorente, Yolanda de Diego-Otero, Michael King, Irwin Nazareth, Blanca Gutierrez, and PREDICT Study Core Group. 2006. "The 5-HTTLPR s/s Genotype at the Serotonin Transporter Gene (SLC6A4) Increases the Risk for Depression in a Large Cohort of Primary Care Attendees: The PREDICT-Gene Study." American Journal of Medical Genetics Part B (Neuropsychiatric Genetics) 141B: 912-917.

Chetty, Raj, Nathaniel Hendren, Patrick Kline, and Emmanuel Saez. 2014. "Where Is the Land of Opportunity? The Geography of Intergenerational Mobility in the United States." Working Paper. Retrieved July 23, 2014 from http://scholar.harvard.edu/files/hendren/files/mobility_geo.pdf.

Chetty, Raj, Nathaniel Hendren, Patrick Kline, and Emmanuel Saez. 2013. "The Economic Impacts of Tax Expenditures: Evidence from Spatial Variation across the U.S." Working Paper. Retrieved July 23, 2014 from http://obs.rc.fas.harvard.edu/chetty/tax_expenditure_soi_whitepaper.pdf.

Clark, Gregory with Neil Cummins, Yu Hao, and Daniel Diaz Vidal. 2014. The Son Also Rises: Surnames and the History of Social Mobility. Princeton, NJ: Princeton University Press.

Conley, Dalton. 2011. "In Search of GE: Why We Have Not Documented a Gene-Social Environment Interaction Yet.” Pp. 231-246 in Biosocial Foundations of Family Processes, edited by A. Booth, S.M. McHale, and N.S. Landale. New York, NY: Springer.

Conley, Dalton and Emily Rauscher. 2013. "Genetic Interactions with Prenatal Social Environment: Effects on Academic and Behavioral Outcomes." Journal of Health and Social Behavior 54(1):109-27.

Conley, Dalton, Emily Rauscher, and Mark Siegal. 2013. "Beyond Orchids and Dandelions: Testing the 5HTT 'Risky' Allele for Evidence of Phenotypic Capacitance and Frequency Dependent Selection” Biodemography and Social Biology 59(1):37-56.

Cook, C. Justin and Jason M. Fletcher. 2015. "Understanding Heterogeneity in the Effects of Birth Weight on Adult Cognition and Wages.” NBER Working Paper No. 20895. 
Cummins, T.D.R., Z. Hawi, J. Hocking, M. Strudwick, R. Hester, H. Garavan, J. Wagner, C.D. Chambers, and M.A. Bellgrove. 2012. "Dopamine Transporter Genotype Predicts Behavioural and Neural Measures of Response Inhibition." Molecular Psychiatry 17: 108692.

Daw, Jonathan, Michael Shanahan, Kathleen Mullan Harris, Andrew Smolen, Brett Haberstick, and Jason D. Boardman. 2013. "Genetic Sensitivity to Peer Behaviors: 5HTTLPR, Smoking, and Alcohol Consumption." Journal of Health and Social Behavior 54(1): 92-108.

Dick, D.M., J.L. Pagan, C. Holliday, R. Viken, L. Pulkkinen, J. Kaprio, and R.J. Rose. 2007. "Gender differences in friends' influences on adolescent drinking: A genetic epidemiological study." Alcoholism: Clinical and Experimental Research 31(12): 2012-19

DiPrete, Thomas A. and David B. Grusky. 1990. "Structure and Trend in the Process of Stratification for American Men and Women." American Journal of Sociology 96: 107-143.

Dominus, Susan. 2015. "The Mixed-Up Brothers of Bogotá.” The New York Times Magazine, July 9. Retrieved September 4, 2015 from www.nytimes.com/2015/07/12/magazine/themixed-up-brothers-of-bogota.html.

Dreber, Anna, Coren L. Apicella, Dan T.A. Eisenberg, Justin R. Garcia, Richard S. Zamore, J. Koji Lum, and Benjamin Campbell. 2009. "The 7R polymorphism in the dopamine receptor D4 gene (DRD4) is associated with financial risk taking in men." Evolution and Human Behavior 30: 85-92.

Duncan, Greg, Ariel Kalil, Susan E. Mayer, Robin Tepper, and Monique R. Payne. 2005. “The Apple Does Not Fall Far from the Tree." In Samuel Bowles, Herbert Gintis, and Melissa Osborne Groves (eds.), Unequal Chances: Family Background and Economic Success. New York: Russell Sage Foundation: 23-79.

Edenberg, Howard J., et al. 2004. "Variations in GABRA2, Encoding the a-2 Subunit of the GABAA Receptor, Are Associated with Alcohol Dependence and with Brain Oscillations." American Journal of Human Genetics 74:705-14.

Eisenegger, Christoph, Daria Knoch, Richard P. Ebstein, Lorena R.R. Gianotti, Peter S. Sandor, and Ernst Fehr. 2010. "Dopamine Receptor D4 Polymorphism Predicts the Effect of LDOPA on Gambling Behavior.” Biological Psychiatry 67: 702-6.

Ellis, B. J. and W. T. Boyce. 2008. Biological Sensitivity to Context. Current Directions in Psychological Science 17: 183-7.

Erikson, Robert and John H. Goldthorpe. 1992. The Constant Flux: A Study of Class Mobility in Industrial Societies. Oxford: Clarendon Press.

Ermisch, John, Markus Jäntti, and Timothy Smeeding. 2012. From Parents to Children: The Intergenerational Transmission of Advantage. New York: Russell Sage Foundation.

Fan, J.B. and P. Sklar. 2005. "Meta-Analysis Reveals Association between Serotonin Transporter Gene Stin2 VNTR Polymorphism and Schizophrenia." Molecular Psychiatry 10:928-38.

Featherman, David L. and Robert M. Hauser. 1978. Opportunity and Change. New York: Academic Press.

Fletcher, Jason M. 2014. "The Effects of Childhood ADHD on Adult Labor Market Outcomes." Health Economics 23(2): 159-181.

Fletcher, Jason M. and Steven F. Lehrer. 2011. "Genetic Lotteries within Families." Journal of Health Economics 30(4): 647-659. 
Foley, D. L., Eaves, L. J., Wormley, B., Silberg, J. L., Maes, H. H., Kuhn, J., and Riley, B. 2004. "Childhood adversity, monoamine oxidase a genotype, and risk for conduct disorder." Archives of General Psychiatry 61: 738-744.

Fowler, James H., Jaime E. Settle, and Nicholas A. Christakis. 2011. "Correlated Genotypes in Friendship Networks." Proceedings of the National Academy of Sciences of the United States of America 108(5):1993-97.

Garmezy, Norman. 1987. "Stress, competence, and development: continuities in the study of schizophrenic adults, children vulnerable to psychopathology, and the search for stressresistant children." American Journal of Orthopsychiatry 57: 159-174.

Gelernter, J. and H. Kranzler. 1999. "D2 Dopamine Receptor Gene (DRD2) Allele and Haplotype Frequencies in Alcohol Dependent and Control Subjects: No Association with Phenotype or Severity of Phenotype." Neuropsychopharmacology 20(6):640-9.

Guo, Guang, Michael E. Roettger, and Tianji Cai. 2008. "The Integration of Genetic Propensities into Social-Control Models of Delinquency and Violence among Male Youths." American Sociological Review 73(4):543-68.

Harris, Kathleen Mullan. 2009. The National Longitudinal Study of Adolescent Health, Waves I \& II, 1994-6; Wave III, 2001-2; Wave IV, 200-9. Chapel Hill, NC: Carolina Population Center.

Herrnstein, Richard J. and Charles Murray. 1994. The Bell Curve: Intelligence and Class Structure in American Life. New York: Free Press.

Hout, Michael. 1988. "More Universalism, Less Structural Mobility: The American Occupational Structure in the 1980s.” American Journal of Sociology 93:1358-1400.

Howell, Kathryn H. and Laura E. Miller-Graff. 2014. "Protective Factors Associated with Resilient Functioning in Young Adulthood after Childhood Exposure to Violence." Child Abuse and Neglect 38(12): 1985-1994.

Hutchison, Kent, John McGeary, and Andrew Smolen et al. 2002. "The DRD4 VNTR Polymorphism Moderates Craving After Alcohol Consumption." Health Psychology 21(2):139-46.

Kassis, Wassilis, Sibylle Artz, Christian Scambor, Elli Scambor, and Stephanie Moldenhauer. 2013. "Finding the Way Out: A Non-Dichotomous Understanding of Violence and Depression Resilience of Adolescents Who Are Exposed to Family Violence." Child Abuse and Neglect 37(2-3): 181-199.

Keltikangas-Jarvinen, L., Elovainio, M., Kivimaki, M., Raitakari, O. T., Viikari, J. S., \& Lehtimaki, T. 2007. "Dopamine receptor D2 gene Taq1A (C32806T) polymorphism modifies the relationship between birth weight and educational attainment in adulthood: 21 year follow-up of the Cardiovascular Risk in Young Finns Study." Pediatrics 120: 756-761.

Kuhnen, Camelia M. and Joan Y. Chiao. 2009. "Genetic Determinants of Financial Risk Taking." PLoS ONE 4(2): e4362.

Lowe, Sara R., Laura Sampson, Oliver Gruebner, Sandro Galea. 2015. "Psychological Resilience after Hurricane Sandy: The Influence of Individual- and Community-Level Factors on Mental Health after a Large-Scale Natural Disaster." PLoS One 10(5): e0125761.

McDermott, Rose, Dustin Tingley, Jonathan Cowden, Giovanni Frazzetto, and Dominic D.P. Johnson. 2009. "Monoamine Oxidase A Gene (MAOA) Predicts Behavioral Aggression Following Provocation." Proceedings of the National Academy of Sciences 106(7): 21182123. 
Mills-Koonce, W. R., Propper, C. B., Gariepy, J. L., Blair, C., Garrett- Peters, P., \& Cox, M. J. 2007. "Bidirectional genetic and environmental influences on mother and child behavior: The family system as the unit of analyses." Development and Psychopathology 19: 1073-1087.

Mitchell, Colter, John Hobcraft, Sara S. McLanahan, Susan Rutherford Siegel, Arthur Berg, Jeanne Brooks-Gunn, Irwin Garfinkel, and Daniel Notterman. 2014. "Social Disadvantage, Genetic Sensitivity, and Children's Telomere Length." Proceedings of the National Academy of Sciences 111(16):5944-5949.

Nam, Yunju, Darrick Hamilton, William A. Darity, and Anne E. Price. 2015. "Bootstraps Are for Black Kids: Race, Wealth, and the Impact of Intergenerational Transfers on Adult Outcomes." Research Brief. Insight: Center for Community Economic Development. Oakland, CA. Retrieved December 1, 2015 from www.insightcced.org/wpcontent/uploads/2015/07/Bootstraps-are-for-Black-Kids-Sept.pdf.

Nilsson, K. W., Sjoberg, R. L., Damberg, M., Leppert, J., Ohrvik, J., Alm, P.O., et al. 2006. "Role of monoamine oxidase A genotype and psychosocial factors in male adolescent criminal activity." Biological Psychiatry 59: 121-127.

Pager, Devah. 2003. "The Mark of a Criminal Record." American Journal of Sociology 108(5): 937-75.

Pearson-Fuhrhop KM, EC Dunn, S Mortero, WJ Devan, GJ Falcone, P Lee, AJ Holmes, MO Hollinshead, JL Roffman, JW Smoller, J Rosand, and SC Cramer. 2014. "Dopamine Genetic Risk Score Predicts Depressive Symptoms in Healthy Adults and Adults with Depression." PLOS One 9(5): e93772.

Pearson-Fuhrhop KM, Minton B, Acevedo D, Shahbaba B, Cramer SC. 2013. "Genetic Variation in the Human Brain Dopamine System Influences Motor Learning and Its Modulation by LDopa." PLoS One 84(4):e61197.

Pescosolido, Bernice A., Brea L. Perry, J. Scott Long, Jack K. Martin; John I. Nurnberger, and Victor Hesselbrock. 2008. "Under the Influence of Genetics: How Transdisciplinarity Leads Us to Rethink Social Pathways to Illness." American Journal of Sociology 114(Suppl.): S171-S201.

Pluess, Michael and Jay Belsky. 2010. “Children's Differential Susceptibility to Effects of Parenting." Family Science 1(1): 14-25.

Pluess, M., Velders, F.P., Belsky, J., van IJzendoorn, M.H., Bakermans-Kranenburg, M.J., Jaddoe, V.W., Hofman, A., Arp, P.P., Verhulst, F., \& Tiemeier, H. 2011. "Serotonin transporter polymorphism moderates effects of prenatal maternal anxiety on infant negative emotionality." Biological Psychiatry 69(6): 520-525.

Pluess, M., Belsky, J., Way, B., \& Taylor, S. 2010. "5-HTTLPR Moderates Effects of Current Life Events on Neuroticism: Differential Susceptibility to Environmental Influences." Progress in Neuro-Psychopharmacology \& Biological Psychiatry 34: 1070-1074.

Propper, C., Moore, G. A., Mills-Koonce, W. R., Halpern, C. T., Hill-Soderlund, A. L., Calkins, S. D., . . \& \& Cox, M. 2008. "Gene- environment contributions to the development of infant vagal reactivity: The interaction of dopamine and maternal sensitivity." Child Development 79: 1377-1394.

Retz ,Wolfgang, Christine Freitag, and Petra Retz- Junginger et al. 2008. “A Functional Serotonin Transporter Promoter Gene Polymorphism Increases ADHD Symptoms in Delinquents: Interaction with Adverse Childhood Environment." Psychiatry Research 158(2):123-31. 
Sabol, Sue Z., Stella Hu, and Dean Hamer. 1998. "A Functional Polymorphism in the Monoamine Oxidase A Gene Promoter." Human Genetics 103(3):273-9.

Sapra, Steve, Laura E. Beavin, Paul J. Zak. 2012. "A Combination of Dopamine Genes Predicts Success by Professional Wall Street Traders.” PLOS One 7(1): e30844.

Seccombe, Karen. 2002. "'Beating the Odds' Versus 'Changing the Odds': Poverty, Resilience, and Family Policy." Journal of Marriage and Family 64: 384-394.

Shanahan, Michael J., Stephen Vaisey, Lance D. Erickson, and Andrew Smolen. 2008. "Environmental Contingencies and Genetic Propensities: Social Capital, Educational Continuation, and DRD2." American Journal of Sociology 114(S1):S260-S86.

Sheese, B. E., Voelker, P. M., Rothbart, M. K., \& Posner, M. I. 2007. "Parenting quality interacts with genetic variation in dopamine receptor D4 to influence temperament in early childhood. Development and Psychopathology 19: 1039-1046.

Simons, Ronald L., Man Kit Lei, Steven R. H. Beach, Gene H. Brody, Robert A. Philibert, and Frederic X. Gibbons. 2011. "Social Environment, Genes, and Aggression: Evidence Supporting the Differential Susceptibility Perspective." American Sociological Review 76(6):883-912.

Solon, Gary. 2002. "Cross-Country Differences in Intergenerational Earnings Mobility.” Journal of Economic Perspectives 16(3): 59-66.

Solon, Gary. 1992. "Intergenerational Income Mobility in the United States." The American Economic Review 82(3): 393-408.

Stice, E., S. Yokum, K. Burger, L. Epstein, and A. Smolen. 2012. "Multilocus Genetic Composite Reflecting Dopamine Signaling Capacity Predicts Reward Circuitry Responsivity." Journal of Neuroscience 32: 10093-10100.

Taylor, S.E., B.M. Way, W.T. Welch, C.J. Hilmert, B.J. Lehman, and N.I. Eisenberger. 2006. "Early family environment, current adversity, the serotonin transporter promoter polymorphism, and depressive symptomatology." Biological Psychiatry 60: 671-676.

Thomas, Duncan C. and John S. Witte. 2002. "Point: Population Stratification: A Problem for Case-Control Studies of Candidate-Gene Associations?" Cancer Epidemiology, Biomarkers \& Prevention 11:505-12.

Thompson, Owen. 2014. "Economic Background and Educational Attainment: The Role of Gene-Environment Interactions." The Journal of Human Resources 49(2): 263-294.

Torche, Florencia. 2011. "Is a College Degree Still the Great Equalizer? Intergenerational Mobility across Levels in the United States.” American Journal of Sociology 117(3): 763807.

Werner, Emmy E. 1993. "Risk, resilience and recovery: perspectives from the Kauai longitudinal study." Development and Psychopathology 5: 503-515.

Wexler, Lisa Marin, Gloria DiFluvio, and Tracey K. Burke. 2009. "Resilience and marginalized youth: Making a case for personal and collective meaning-making as part of resilience research in public health." Social Science and Medicine 69: 565-570.

Whitfield, John B., et al. 2004. "The Genetics of Alcohol Intake and of Alcohol Dependence." Alcohol Clinical Experimental Research 28:1153-60.

Wilhelm, Kay, Philip Mitchell, and Heather Niven, et al. 2006. "Life Events, First Depression Onset and the Serotonin Transporter Gene." British Journal of Psychiatry: The Journal of Mental Science 188:210-15.

Zhong, Songfa, Salomon Israel, Hong Xue, Richard P. Ebstein, and Soo Hong Chew. 2009a. "Monoamine Oxidase A Gene (MAOA) Associated with Attitude Towards Longshot Risks." PLoS ONE 4(12): e8516. 
Zhong, Songfa, Salomon Israel, Hong Xue, Pak C. Sham, Richard P. Ebstein, and Soo Hong Chew. 2009b. "A Neurochemical Approach to Valuation Sensitivity over Gains and Losses." Proceedings of the Royal Society B 276(1676): 4181-4188. 


\section{Tables and Figures}

Table 1: Descriptive Information - Add Health Sibling Sample

\begin{tabular}{|c|c|c|c|c|}
\hline & All & Std Dev & $\begin{array}{l}\text { Low Parent } \\
\text { Hh Income }\end{array}$ & $\begin{array}{l}\text { High Parent } \\
\text { Hh Income }\end{array}$ \\
\hline Young Adult Financial Standing & & & & \\
\hline Household Income & $\$ 63,666.67$ & $\$ 38,894.81$ & $\$ 54,084.97$ & $\$ 72,716.05$ \\
\hline$\%$ Federal Poverty Level+ & 379.77 & 249.08 & 313.07 & 441.52 \\
\hline Individual Earnings $\dagger$ & $\$ 33,981.29$ & $\$ 32,176.92$ & $\$ 30,300.26$ & $\$ 37,478.28$ \\
\hline Household Net Worth $\$$ & $\$ 54,204.79$ & $\$ 160,419.00$ & $\$ 38,566.18$ & $\$ 68,772.26$ \\
\hline Genetic Sensitivity Score & 3.89 & 1.34 & 3.83 & 3.94 \\
\hline Male & 0.45 & 0.50 & 0.46 & 0.44 \\
\hline Age - Child & 15.71 & 1.71 & 15.67 & 15.75 \\
\hline Age - Young Adult & 28.55 & 1.75 & 28.57 & 28.54 \\
\hline Income (2007 \$) & $\$ 67,013.33$ & $\$ 60,621.72$ & $\$ 30,836.60$ & $\$ 101,180.20$ \\
\hline Responding Parent $A$ & 41.01 & 5.04 & 40.31 & 41.68 \\
\hline $\mathrm{N}$ & 630 & & 306 & 324 \\
\hline $\mathrm{N}+$ & 624 & & 300 & 324 \\
\hline $\mathrm{N} \dagger$ & 624 & & 304 & 320 \\
\hline $\mathrm{N}$ & 564 & & 272 & 292 \\
\hline
\end{tabular}

Source: Add Health Data Waves I and IV. Includes same sex singleton full sibling pairs with complete information about parental income (Wave I), individual financial standing (Wave IV), and genetic sensitivity score (Wave IV).

Low and high parent household income includes those below and above median parental income $(\$ 56,000)$.

Table 2: Frequency Distribution of the Sibling Sample by Pair GSS Difference

\begin{tabular}{|crr|}
\hline Absolute Value of GSS Difference & N & \% of Sample \\
\hline 0 & 188 & 29.84 \\
1 & 268 & 42.54 \\
2 & 138 & 21.9 \\
3 & 32 & 5.08 \\
4 & 2 & 0.32 \\
5 & 2 & 0.32 \\
\hline & 630 & 100.00 \\
\hline
\end{tabular}

Source: Add Health Data Waves I and IV. Includes same sex singleton full sibling pairs with complete information about parental income (Wave I), individual financial standing (Wave IV), and genetic sensitivity score (Wave IV).

GSS $=$ Genetic Sensitivity Score 
Table 3: Mean Sibling Pair Differences in Adult Financial Standing by Parental Household Income - Sibling with Higher GSS Minus Sibling with Lower GSS

\begin{tabular}{|c|c|c|c|c|c|}
\hline & $\begin{array}{l}\text { Low Parent } \\
\text { Hh Income }\end{array}$ & $\mathrm{N}$ (Pairs) & $\begin{array}{l}\text { High Parent } \\
\text { Hh Income }\end{array}$ & N (Pairs) & $\begin{array}{l}\text { T-Test of } \\
\text { Differenc } \\
\text { e }\end{array}$ \\
\hline Hh Income & -11689.19 & 111 & 10977.27 & 110 & $* *$ \\
\hline \% Poverty Level x 100 & -49.56 & 110 & 75.55 & 110 & $* *$ \\
\hline Indiv Earnings & -10414.05 & 111 & 5875.45 & 109 & $* *$ \\
\hline Hh Net Worth & -33233.01 & 103 & 44683.67 & 98 & $*$ \\
\hline
\end{tabular}

Source: Add Health Data Waves I and IV; same sex singleton full sibling pairs with complete information, who differ in GSS.

GSS = Genetic Sensitivity Score

Sibling pair differences are calculated as the financial outcome value for the sibling with the higher GSS minus the value for the sibling with the lower GSS.

$* \mathrm{p}<0.05 ; * * \mathrm{p}<0.01$ (two-tailed t-test) 
Table 4: Regressions Predicting Young Adult Financial Outcomes: Full Sample

\begin{tabular}{|c|c|c|c|c|c|c|c|c|}
\hline VARIABLES & $\begin{array}{c}(1) \\
\sqrt{H h} \\
\text { Income }\end{array}$ & $\begin{array}{c}(2) \\
\% \mathrm{FPL}\end{array}$ & $\begin{array}{c}(3) \\
\sqrt{\text { Earnings }}\end{array}$ & $\begin{array}{c}\text { (4) } \\
\text { IHS Hh } \\
\text { Net Worth } \\
\end{array}$ & $\begin{array}{c}(5) \\
\sqrt{\mathrm{Hh}} \\
\text { Income } \\
\end{array}$ & $\begin{array}{c}(6) \\
\% \mathrm{FPL}\end{array}$ & $\begin{array}{c}(7) \\
\sqrt{\text { Earnings }}\end{array}$ & $\begin{array}{c}(8) \\
\text { IHS Hh } \\
\text { Net Worth } \\
\end{array}$ \\
\hline Genetic Sensitivity Score & $\begin{array}{l}1.12 \\
(2.84)\end{array}$ & $\begin{array}{c}2.78 \\
(8.41)\end{array}$ & $\begin{array}{l}-0.05 \\
(2.42)\end{array}$ & $\begin{array}{c}0.23 \\
(0.24)\end{array}$ & $\begin{array}{l}-0.74 \\
(2.76)\end{array}$ & $\begin{array}{c}0.71 \\
(8.96)\end{array}$ & $\begin{array}{c}-5.09+ \\
(2.77)\end{array}$ & $\begin{array}{c}0.23 \\
(0.33)\end{array}$ \\
\hline$\sqrt{ }$ Hh Income & $\begin{array}{c}0.24 * * \\
(0.04)\end{array}$ & $\begin{array}{c}0.88 * * \\
(0.14)\end{array}$ & $\begin{array}{c}0.16 * * \\
(0.04)\end{array}$ & $\begin{array}{l}0.01+ \\
(0.00)\end{array}$ & $\begin{array}{c}0.12 * * \\
(0.04)\end{array}$ & $\begin{array}{c}0.54 * * \\
(0.15)\end{array}$ & $\begin{array}{c}0.01 \\
(0.04)\end{array}$ & $\begin{array}{c}0.01 \\
(0.01)\end{array}$ \\
\hline GSS $x \sqrt{ }$ Hh Income & $\begin{array}{l}-0.00 \\
(0.01)\end{array}$ & $\begin{array}{l}-0.00 \\
(0.04)\end{array}$ & $\begin{array}{c}0.00 \\
(0.01)\end{array}$ & $\begin{array}{l}-0.00 \\
(0.00)\end{array}$ & $\begin{array}{c}0.00 \\
(0.01)\end{array}$ & $\begin{array}{l}-0.01 \\
(0.04)\end{array}$ & $\begin{array}{l}0.02+ \\
(0.01)\end{array}$ & $\begin{array}{l}-0.00 \\
(0.00)\end{array}$ \\
\hline Age & $\begin{array}{c}2.55^{* *} * \\
(0.64)\end{array}$ & $\begin{array}{l}4.76^{*} \\
(1.93)\end{array}$ & $\begin{array}{c}3.31 * * \\
(0.64)\end{array}$ & $\begin{array}{l}0.14+ \\
(0.08)\end{array}$ & $\begin{array}{l}4.41 * * \\
(0.76)\end{array}$ & $\begin{array}{l}8.59 * * \\
(2.36)\end{array}$ & $\begin{array}{c}4.55 * * \\
(0.80)\end{array}$ & $\begin{array}{l}0.18+ \\
(0.10)\end{array}$ \\
\hline Male & $\begin{array}{c}9.03 * * \\
(2.25)\end{array}$ & $\begin{array}{c}40.57 * * \\
(6.93)\end{array}$ & $\begin{array}{c}38.90^{* *} \\
(2.28)\end{array}$ & $\begin{array}{l}1.99 * * \\
(0.28)\end{array}$ & $\begin{array}{l}6.28^{*} \\
(2.64)\end{array}$ & $\begin{array}{c}33.06^{* *} \\
(8.31)\end{array}$ & $\begin{array}{c}41.01 * * \\
(2.76)\end{array}$ & $\begin{array}{l}1.52 * * \\
(0.35)\end{array}$ \\
\hline Highest Parental Education & & & & & $\begin{array}{c}2.30 * * \\
(0.74)\end{array}$ & $\begin{array}{c}13.01 * * \\
(2.32)\end{array}$ & $\begin{array}{l}2.23 * * \\
(0.71)\end{array}$ & $\begin{array}{l}-0.11 \\
(0.09)\end{array}$ \\
\hline Received AFDC Last Month & & & & & $\begin{array}{c}-16.63 * \\
(8.34)\end{array}$ & $\begin{array}{l}-21.36 \\
(20.48)\end{array}$ & $\begin{array}{c}3.70 \\
(11.18)\end{array}$ & $\begin{array}{c}0.43 \\
(1.28)\end{array}$ \\
\hline Have Enough Money for Bills & & & & & $\begin{array}{l}-1.64 \\
(4.27)\end{array}$ & $\begin{array}{c}-13.27 \\
(13.04)\end{array}$ & $\begin{array}{c}2.19 \\
(4.40)\end{array}$ & $\begin{array}{l}0.94+ \\
(0.56)\end{array}$ \\
\hline Received Food Stamps Last Month & & & & & $\begin{array}{c}-24.37 * * \\
(6.39)\end{array}$ & $\begin{array}{c}-51.74 * * \\
(16.15)\end{array}$ & $\begin{array}{c}-16.63 * * \\
(6.27)\end{array}$ & $\begin{array}{l}-0.16 \\
(0.99)\end{array}$ \\
\hline Parent 1 Excellent Health & & & & & $\begin{array}{l}6.86^{*} \\
(3.14)\end{array}$ & $\begin{array}{c}34.81 * * \\
(10.52)\end{array}$ & $\begin{array}{c}10.16^{* *} \\
(3.56)\end{array}$ & $\begin{array}{c}0.08 \\
(0.41)\end{array}$ \\
\hline Parent 1 Alcohol Frequency & & & & & $\begin{array}{c}2.27 \\
(1.40)\end{array}$ & $\begin{array}{l}10.78^{*} \\
(4.47)\end{array}$ & $\begin{array}{l}3.03^{*} \\
(1.42)\end{array}$ & $\begin{array}{l}-0.01 \\
(0.18)\end{array}$ \\
\hline Parent 1 Smokes & & & & & $\begin{array}{l}-4.56 \\
(3.18)\end{array}$ & $\begin{array}{l}-15.48 \\
(9.93)\end{array}$ & $\begin{array}{l}-1.74 \\
(3.54)\end{array}$ & $\begin{array}{l}-0.55 \\
(0.44)\end{array}$ \\
\hline Parent 1 Age & & & & & $\begin{array}{c}-0.46+ \\
(0.25)\end{array}$ & $\begin{array}{c}0.99 \\
(0.76)\end{array}$ & $\begin{array}{c}0.25 \\
(0.28)\end{array}$ & $\begin{array}{c}0.05 \\
(0.03)\end{array}$ \\
\hline Parent 1 Unemployed & & & & & $\begin{array}{c}1.73 \\
(6.78)\end{array}$ & $\begin{array}{c}-3.27 \\
(19.07)\end{array}$ & $\begin{array}{l}-7.28 \\
(6.58)\end{array}$ & $\begin{array}{c}0.27 \\
(0.86)\end{array}$ \\
\hline
\end{tabular}




\section{Parent 1 Married}

Parent 1 Is Biological Mother

\section{Parent 1 White}

Parent 1 Latino

Parent 1 Always Wears Seatbelt

Parent 2 Employed

Parent 2 Unemployed

Parent 2 White

Parent 2 Alcohol Frequency

Parent 2 Latino

Household Size

Birth Weight - log ounces

Special Educ Service - past year

Mentally Retarded

Learning Disability

Constant

\begin{tabular}{|c|c|c|c|c|c|c|c|}
\hline & & & & $\begin{array}{c}4.73 \\
(5.34)\end{array}$ & $\begin{array}{c}1.66 \\
(14.29)\end{array}$ & $\begin{array}{c}7.31 \\
(5.37)\end{array}$ & $\begin{array}{c}0.31 \\
(0.69)\end{array}$ \\
\hline & & & & $9.13+$ & $45.18 * *$ & $13.70 *$ & 0.42 \\
\hline & & & & $(5.24)$ & (15.08) & $(5.75)$ & $(0.69)$ \\
\hline & & & & $12.39+$ & 27.96 & 7.98 & -0.77 \\
\hline & & & & $(6.98)$ & (21.38) & (9.49) & $(0.93)$ \\
\hline & & & & -0.04 & -18.44 & 8.49 & -0.07 \\
\hline & & & & (6.99) & (19.08) & (6.37) & $(0.95)$ \\
\hline & & & & 3.24 & 5.10 & 4.03 & 0.19 \\
\hline & & & & $(2.87)$ & $(9.23)$ & (2.99) & $(0.39)$ \\
\hline & & & & 9.53 & 12.94 & -6.33 & 0.92 \\
\hline & & & & $(5.84)$ & (19.64) & (9.14) & $(0.86)$ \\
\hline & & & & $17.24+$ & 3.70 & -10.68 & 0.62 \\
\hline & & & & $(9.72)$ & $(27.34)$ & (12.66) & (1.47) \\
\hline & & & & -4.79 & -1.95 & -7.88 & 1.31 \\
\hline & & & & (6.91) & $(21.74)$ & $(9.85)$ & $(0.93)$ \\
\hline & & & & 1.00 & $5.55+$ & 0.27 & 0.06 \\
\hline & & & & $(1.00)$ & (3.06) & $(0.93)$ & $(0.13)$ \\
\hline & & & & $24.60 * *$ & $65.37 * *$ & 6.55 & $1.62+$ \\
\hline & & & & $(7.08)$ & (20.89) & (6.72) & $(0.95)$ \\
\hline & & & & 0.04 & -5.01 & 0.94 & $-0.28+$ \\
\hline & & & & (1.07) & (3.08) & (1.13) & $(0.14)$ \\
\hline & & & & 12.47 & 40.31 & $16.87 *$ & -0.28 \\
\hline & & & & (8.36) & $(25.43)$ & $(8.31)$ & (1.07) \\
\hline & & & & $-25.48 * *$ & $-58.38 * *$ & $-11.26+$ & -0.04 \\
\hline & & & & $(6.18)$ & (19.30) & $(6.40)$ & $(0.84)$ \\
\hline & & & & -42.37 & -70.70 & $-97.58 * *$ & -4.34 \\
\hline & & & & $(35.00)$ & $(51.15)$ & $(15.02)$ & $(3.70)$ \\
\hline & & & & $-14.01 * *$ & $-45.32 * *$ & $-20.59 * *$ & 0.59 \\
\hline & & & & $(4.82)$ & $(15.44)$ & $(4.60)$ & $(0.68)$ \\
\hline $100.15^{* *}$ & 12.99 & 12.25 & -3.79 & -17.74 & $-463.16^{* *}$ & $-124.67 * *$ & -5.36 \\
\hline$(21.59)$ & $(63.54)$ & $(21.91)$ & $(2.45)$ & (49.34) & $(147.91)$ & $(46.16)$ & $(6.21)$ \\
\hline 10,423 & 10,326 & 10,346 & 9,880 & 6,528 & 6,479 & 6,482 & 6,104 \\
\hline
\end{tabular}


R-squared

0.08

0.11

0.10

0.02

0.12

0.14

0.13

0.02

(Wave IV), and genetic sensitivity score (Wave IV) and is weighted to represent the population.

GSS $=$ Genetic Sensitivity Score

Robust standard errors in parentheses, adjusted for family level clustering.

$+\mathrm{p}<0.1, * \mathrm{p}<0.05, * * \mathrm{p}<0.01$ 
Table 5: Regressions Predicting Young Adult Financial Outcomes: Family Fixed Effects

\begin{tabular}{|c|c|c|c|c|}
\hline VARIABLES & $\begin{array}{c}(1) \\
\sqrt{H h} \text { Income }\end{array}$ & $\begin{array}{c}(2) \\
\% \mathrm{FPL}\end{array}$ & $\begin{array}{c}(3) \\
\sqrt{\text { Earnings }}\end{array}$ & $\begin{array}{c}\text { (4) } \\
\text { IHS Hh } \\
\text { Net Worth }\end{array}$ \\
\hline Genetic Sensitivity Score & $\begin{array}{c}-27.71 * * \\
(8.72)\end{array}$ & $\begin{array}{c}-74.58 * * \\
(25.19)\end{array}$ & $\begin{array}{l}-23.80 * \\
(10.63)\end{array}$ & $\begin{array}{c}1.50 \\
(1.37)\end{array}$ \\
\hline Genetic Sensitivity Score $x \sqrt{ }$ Hh Income & $\begin{array}{c}0.11 * * \\
(0.03)\end{array}$ & $\begin{array}{c}0.35 * * \\
(0.10)\end{array}$ & $\begin{array}{l}0.10^{*} \\
(0.04)\end{array}$ & $\begin{array}{l}-0.00 \\
(0.01)\end{array}$ \\
\hline Age & $\begin{array}{c}8.17 * * \\
(1.91)\end{array}$ & $\begin{array}{l}12.93^{*} \\
(6.04)\end{array}$ & $\begin{array}{l}8.15^{* *} \\
(1.86)\end{array}$ & $\begin{array}{c}0.24 \\
(0.31)\end{array}$ \\
\hline Constant & $\begin{array}{c}13.63 \\
(56.76)\end{array}$ & $\begin{array}{c}-27.68 \\
(179.92)\end{array}$ & $\begin{array}{r}-71.05 \\
(56.41)\end{array}$ & $\begin{array}{l}-4.82 \\
(9.17)\end{array}$ \\
\hline Observations & 630 & 624 & 624 & 564 \\
\hline R-squared & 0.08 & 0.04 & 0.07 & 0.01 \\
\hline Number of Sibling Pairs & 315 & 312 & 312 & 282 \\
\hline
\end{tabular}

Source: Add Health Data Waves I and IV. Sibling sample includes same sex singleton full sibling pairs with complete information about parental income (Wave I), individual income (Wave IV), and genetic sensitivity score (Wave IV).

Robust standard errors in parentheses, adjusted for family level clustering.

$+\mathrm{p}<0.1, * \mathrm{p}<0.05, * * \mathrm{p}<0.01$ 
Table 6: Genetic Sensitivity Score Coefficients in Family Fixed Effects Regressions Predicting Young Adult Financial Outcomes

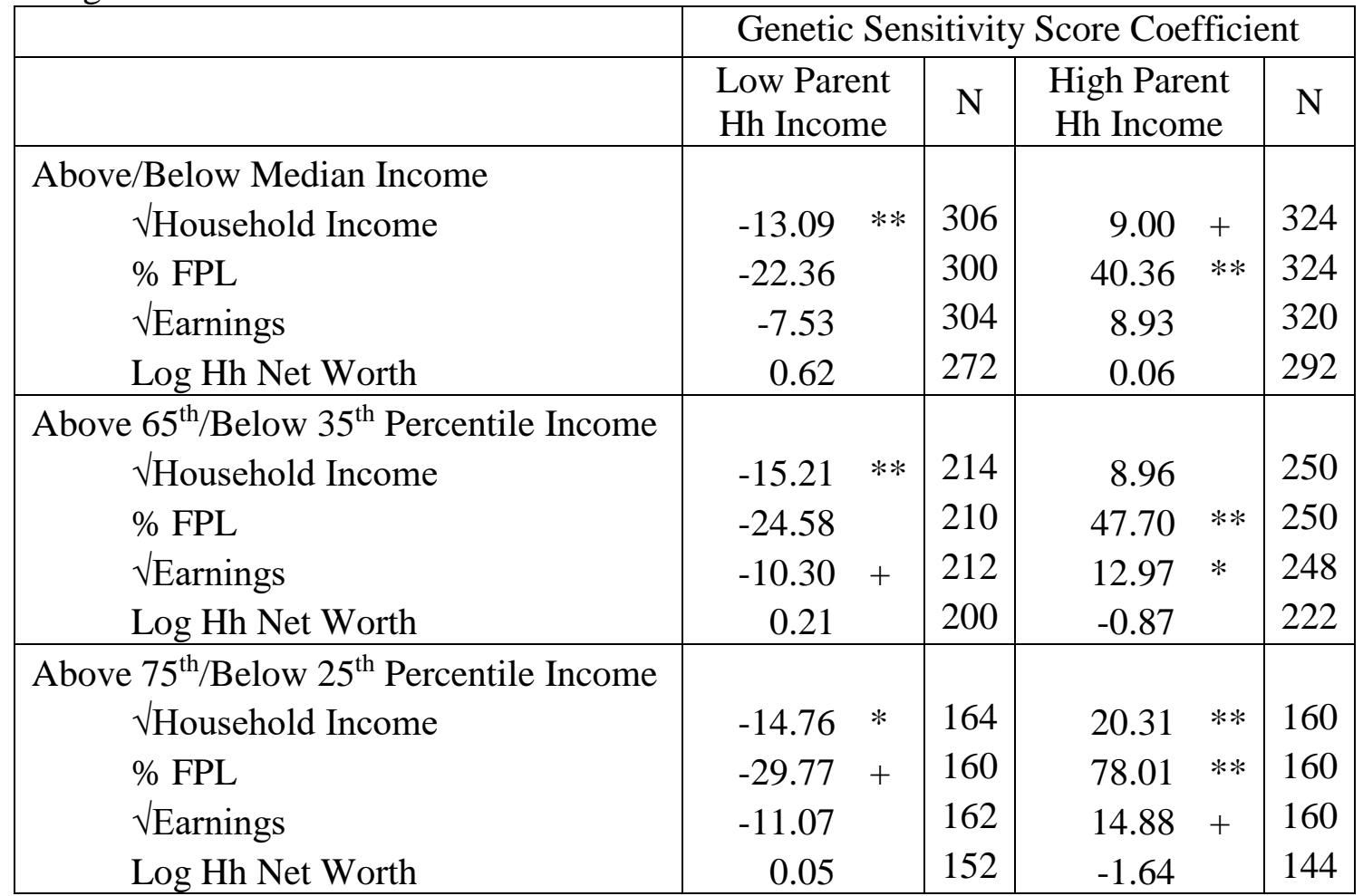

Source: Add Health Data Waves I and IV. Includes same sex singleton full sibling pairs with complete information about parental income (Wave I), individual income (Wave IV), and genetic sensitivity score (Wave IV), limited to pairs with total parental income above and below the median parental income ( $\$ 56,000$ in 2007 dollars), above the $65^{\text {th }}$ or $75^{\text {th }}$ percentiles $(\$ 70,000$ or $\$ 81,000)$, or below the $35^{\text {th }}$ or $25^{\text {th }}$ percentiles $(\$ 39,000$ or $\$ 34,000)$.

Robust standard errors adjusted for family level clustering are not shown.

$+\mathrm{p}<0.1, * \mathrm{p}<0.05, * * \mathrm{p}<0.01$ 
Figure 1: Mean Sibling Pair Differences in Adult Financial Standing by Parental Household Income

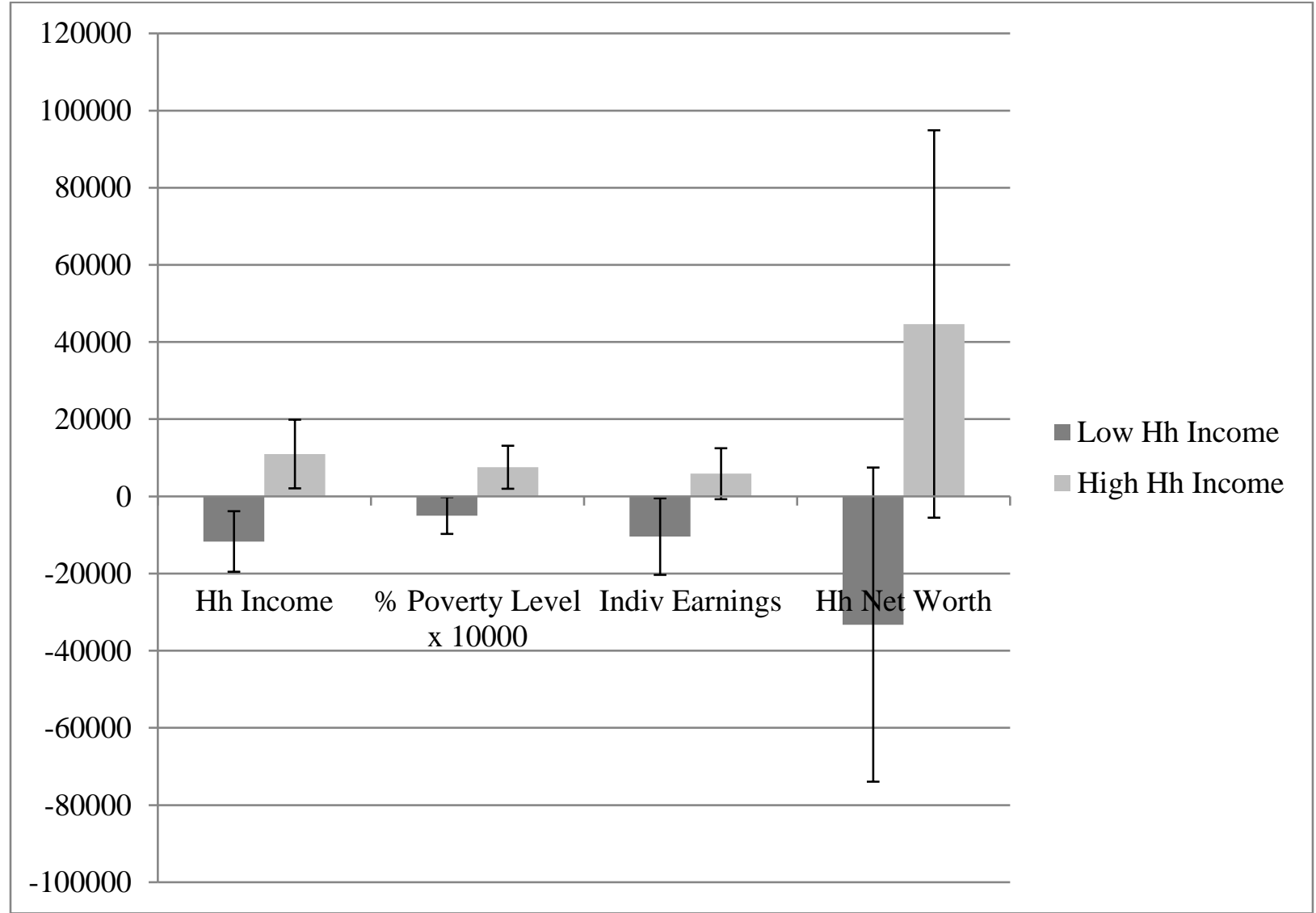

Source: Add Health Data Waves I and IV; same sex singleton full sibling pairs with complete information, who differ in Genetic Sensitivity Score (GSS).

Sibling pair differences are calculated as the financial outcome value for the sibling with the higher GSS minus the value for the sibling with the lower GSS. 
Figure 2: Predicted Relationship between Parent and Child Household Income by Genetic Sensitivity Score: Sibling Fixed Effects Model, $\mathrm{p}<0.01$

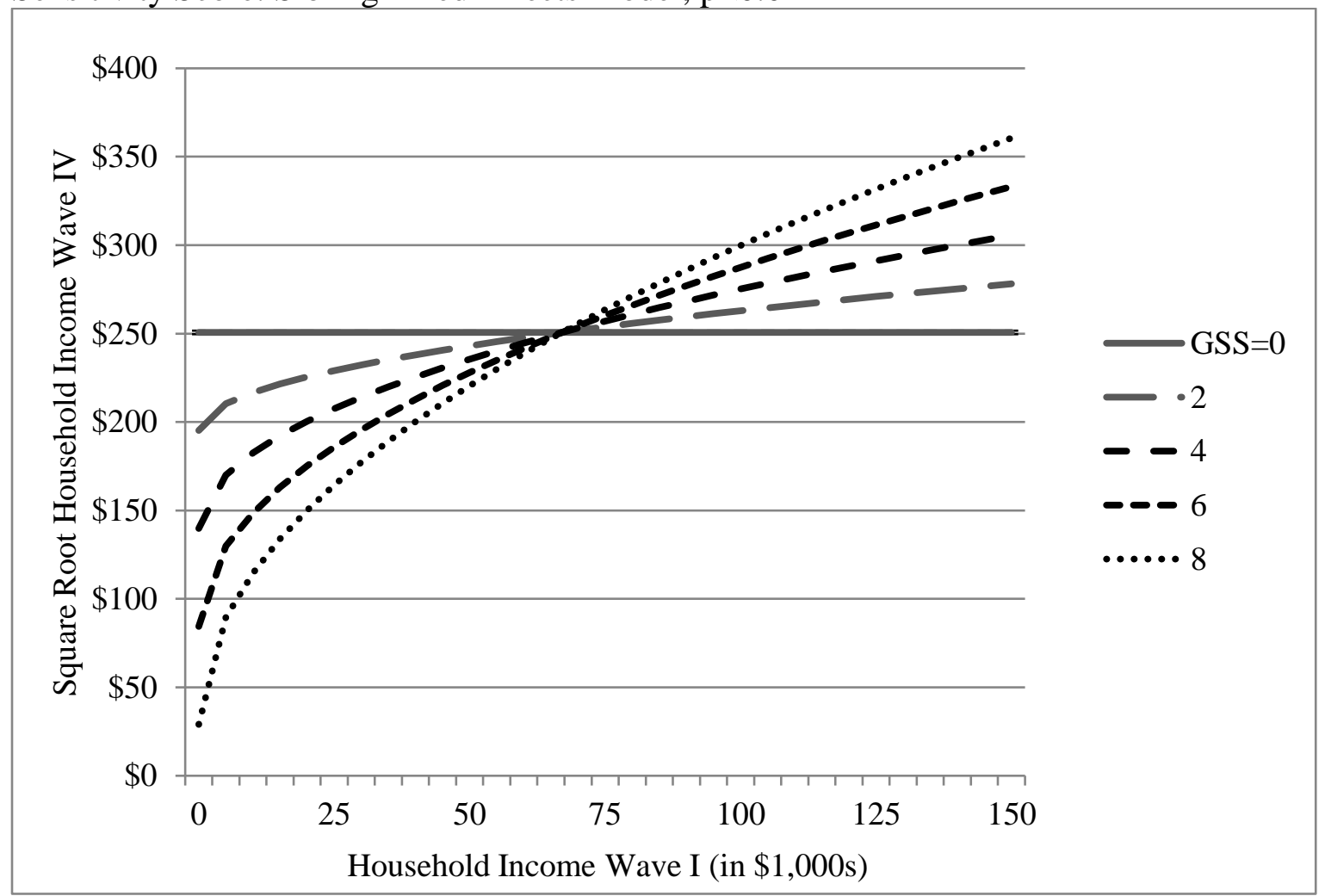

Source: Add Health Data Waves I and IV; based on Table 5, Model 1.

GSS = Genetic Sensitivity Score

Compared to one's same sex full sibling, income as a young adult depends more strongly on parental income among those with a higher number of sensitive alleles. Children with a higher GSS fare more poorly than their sibling if they grew up in a lower income household, but fare better than their sibling if they grew up in a higher income household. 
Figure 3: Financial Return to Parental Household Income by Genetic Sensitivity Score

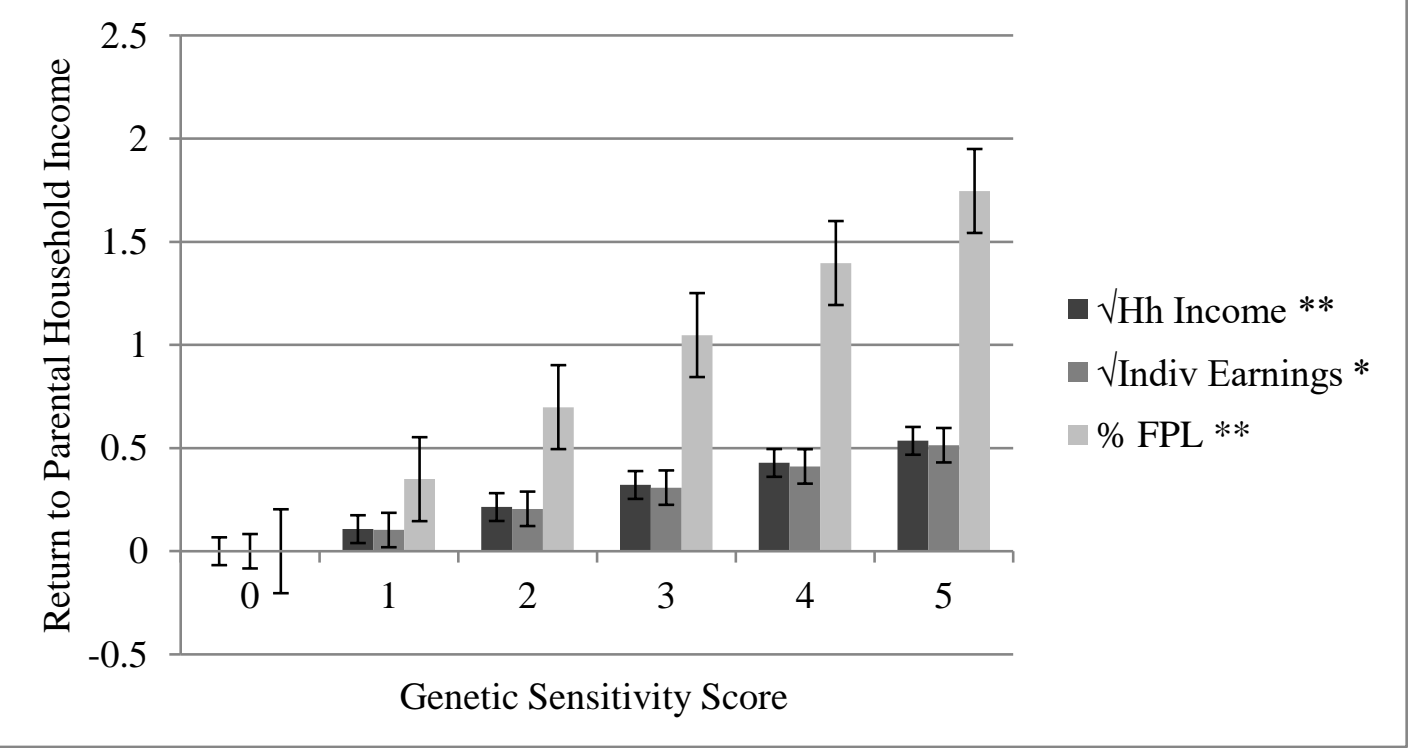

Source: Add Health Data Waves I and IV; based on Table 5, Models 1-3.

Compared to one's same sex full sibling, financial standing as an adult depends more strongly on parental income among those with a higher number of sensitive alleles. 


\section{Appendix}

\section{The Relationship between Sensitive Genotypes and Financial Outcomes}

Evidence suggests that variation at the genetic locations examined in this study may be directly associated with financial outcomes (Sapra et al. 2012; Carpenter et al. 2011; Eisenegger et al. 2010). For example, recent experimental evidence (Kuhnen and Chiao 2009; Dreber et al. 2009) suggests that the long 5-HTT allele and the 7-repeat DRD4 allele are positively associated with risk taking in financial investment decisions. Carpenter et al. (2011) find that the 7-repeat DRD4 allele is associated with risk-taking in economic experiments and predicts financial choice patterns. Zhong et al. (2009a) find an association between MAOA allele and preference for longshot financial risks. In another study, Zhong et al. (2009b) find an association between DAT1 genotype and risk tolerance in financial decisions. The body of research linking genotype to financial decision making is growing, but tends to rely on experimental evidence (e.g., Carpenter et al. 2011; Dreber et al. 2009; Zhong et al. 2009a, 2009b). Although real life financial decision making may differ from that in the lab, the genetic variants examined here are not only associated with individual sensitivity to context (Belsky and Pluess 2009), they may also be associated with financial outcomes either directly through financial decision making or indirectly through health and behavioral measures such as ADHD (Fletcher 2014). 


\section{Supplementary Add Health Tables}

Table S1: Descriptive Information - Add Health Full Sample

\begin{tabular}{|l|rrrr|}
\hline & & & Low Parent & High Parent \\
& All & Std Dev & Hh Income & Hh Income \\
\hline Young Adult Financial Standing & & & & \\
$\quad$ \%ousehold Income & $\$ 61,920.10$ & 39629.40 & $\$ 52,285.09$ & $\$ 71,476.18$ \\
$\quad$ Individual Earnings $\dagger$ & 380.77 & 259.25 & 306.02 & 454.11 \\
$\quad$ Household Net Worth $\$$ & $\$ 34,535.16$ & 42462.24 & $\$ 29,059.28$ & $\$ 39,945.74$ \\
Genetic Sensitivity Score & $\$ 51,583.06$ & 152240.40 & $\$ 37,065.64$ & $\$ 65,971.10$ \\
Male & 3.75 & 1.44 & 3.80 & 3.70 \\
Age - Child & 0.51 & 0.50 & 0.50 & 0.52 \\
Age - Young Adult & 15.32 & 1.79 & 15.27 & 15.37 \\
Parent Household Income $(2007 \$)$ & 28.22 & 1.82 & 28.20 & 28.23 \\
Highest Parental Education & $\$ 64,382.40$ & 65444.80 & $\$ 29,661.44$ & $\$ 98,818.88$ \\
Received AFDC Last Month & 13.48 & 2.28 & 12.47 & 14.47 \\
Have Enough Money for Bills & 0.07 & 0.26 & 0.13 & 0.01 \\
Received Food Stamps Last Month & 0.82 & 0.38 & 0.72 & 0.93 \\
Parent 1 Excellent Health & 0.12 & 0.33 & 0.24 & 0.01 \\
Parent 1 Alcohol Frequency & 0.22 & 0.42 & 0.16 & 0.29 \\
Parent 1 Smokes & 1.03 & 1.18 & 0.84 & 1.21 \\
Parent 1 Age & 0.31 & 0.46 & 0.40 & 0.22 \\
Parent 1 Works & 41.35 & 6.38 & 40.63 & 42.08 \\
Parent 1 Unemployed & 0.75 & 0.43 & 0.69 & 0.81 \\
Parent 1 Out of Labor Force & 0.05 & 0.22 & 0.08 & 0.02 \\
Parent 1 Married & 0.20 & 0.40 & 0.23 & 0.17 \\
Parent 1 Is Biological Mother & 0.72 & 0.45 & 0.56 & 0.89 \\
Parent 1 Always Wears Seatbelt & 0.90 & 0.30 & 0.89 & 0.90 \\
Parent 1 White & 0.64 & 0.48 & 0.58 & 0.71 \\
Parent 1 Black & 0.79 & 0.41 & 0.70 & 0.87 \\
Parent 1 Native American & 0.14 & 0.35 & 0.21 & 0.07 \\
Parent 1 Asian & 0.03 & 0.16 & 0.04 & 0.02 \\
Parent 1 Other Race & 0.03 & 0.17 & 0.03 & 0.03 \\
Parent 1 Latino & 0.04 & 0.19 & 0.05 & 0.02 \\
Parent 2 Works & 0.09 & 0.29 & 0.14 & 0.05 \\
Parent 2 Unemployed & 0.91 & 0.28 & 0.84 & 0.96 \\
Parent 2 Out of Labor Force & 0.02 & 0.14 & 0.04 & 0.01 \\
Parent 2 White & 0.07 & 0.25 & 0.13 & 0.03 \\
Parent 2 Black & 0.82 & 0.38 & 0.74 & 0.88 \\
Parent 2 Native American & 0.11 & 0.31 & 0.16 & 0.07 \\
& 0.02 & 0.14 & 0.03 & 0.02
\end{tabular}




\begin{tabular}{|c|c|c|c|c|}
\hline Parent 2 Asian & 0.03 & 0.17 & 0.03 & 0.03 \\
\hline Parent 2 Other & 0.04 & 0.20 & 0.06 & 0.03 \\
\hline Parent 2 Latino & 0.09 & 0.28 & 0.14 & 0.04 \\
\hline Parent 2 Alcohol Frequency & 1.63 & 1.58 & 1.40 & 1.79 \\
\hline Household Size & 4.48 & 1.51 & 4.53 & 4.44 \\
\hline Birth Weight (ounces) & 119.54 & 19.33 & 117.31 & 121.66 \\
\hline Special Education Service (past year) & 0.09 & 0.29 & 0.12 & 0.07 \\
\hline Mentally Retarded & 0.01 & 0.09 & 0.01 & 0.00 \\
\hline Learning Disability & 0.13 & 0.33 & 0.15 & 0.10 \\
\hline $\mathrm{N}$ & 10423 & & 5139 & 5284 \\
\hline $\mathrm{N}+$ & 10326 & & 5077 & 5249 \\
\hline $\mathrm{N} \dagger$ & 10346 & & 5092 & 5254 \\
\hline $\mathrm{N} t$ & 9880 & & 4873 & 5007 \\
\hline
\end{tabular}

Source: Add Health Data Waves I and IV. Includes all individuals with complete information about parental income (Wave I), individual financial standing (Wave IV), and genetic sensitivity score (Wave IV), weighted to represent the population.

Low and high parent household income includes those below and above median parental income $(\$ 56,000)$. Individuals can indicate more than one race category, so categories are not mutually exclusive. 
Table S2: Characteristics of Sibling Pairs by Similarity of Genetic Sensitivity Score

\begin{tabular}{|c|c|c|c|}
\hline \multirow{2}{*}{\begin{tabular}{|l} 
Young Adult Financial Standing \\
\end{tabular}} & \multicolumn{2}{|c|}{ Discordant Concordant } & \multirow[t]{2}{*}{ Difference } \\
\hline & & & \\
\hline Household Income & 64287.33 & 70744.68 & -6457.35 \\
\hline$\%$ Federal Poverty Level ${ }^{\mathrm{a}}$ & 380.38 & 424.37 & -43.99 \\
\hline Individual Earnings ${ }^{b}$ & 35980.73 & 35659.99 & 320.74 \\
\hline Household Net Worth $^{\mathrm{c}}$ & 57409.95 & 65668.54 & -8258.59 \\
\hline Young Adult Measures & & & \\
\hline Genetic Sensitivity Score & 3.87 & 4.01 & -0.14 \\
\hline Male & 0.43 & 0.48 & -0.04 \\
\hline Age - Child & 15.59 & 15.88 & -0.29 \\
\hline Age - Young Adult & 28.45 & 28.72 & -0.27 \\
\hline Parental Household Measures & & & \\
\hline Parent Household Income (2007 \$) & 67066.97 & 66887.23 & 179.74 \\
\hline Parental Education - Maximum ${ }^{\text {a }}$ & 13.75 & 13.62 & 0.14 \\
\hline Parental Education - Average ${ }^{a}$ & 13.20 & 13.17 & 0.03 \\
\hline Parent $\%$ Federal Poverty Level & 271.84 & 278.00 & -6.16 \\
\hline Poverty & 0.17 & 0.13 & 0.04 \\
\hline Near Poverty & 0.46 & 0.46 & 0.00 \\
\hline Welfare Receipt ${ }^{a}$ & 0.08 & 0.06 & 0.02 \\
\hline AFDC Receipt & 0.05 & 0.03 & 0.02 \\
\hline Enough Money for Bills ${ }^{d}$ & 0.79 & 0.86 & -0.07 \\
\hline Foodstamps ${ }^{\mathrm{e}}$ & 0.10 & 0.09 & 0.02 \\
\hline Household Size & 5.08 & 5.19 & -0.11 \\
\hline Responding Parent Measures & & & \\
\hline Excellent Health ${ }^{b}$ & 0.19 & 0.22 & -0.02 \\
\hline Alcohol Frequency & 0.89 & 0.83 & 0.06 \\
\hline Smokes & 0.22 & 0.27 & -0.04 \\
\hline $\mathrm{Age}^{\mathrm{a}}$ & 40.94 & 41.18 & -0.24 \\
\hline Works $^{\text {a }}$ & 0.75 & 0.76 & -0.01 \\
\hline Unemployed ${ }^{b}$ & 0.05 & 0.06 & -0.01 \\
\hline Out of the Labor Force & 0.20 & 0.18 & 0.02 \\
\hline Married $^{\mathrm{a}}$ & 0.78 & 0.83 & -0.05 \\
\hline Is Biological Mother ${ }^{\mathrm{f}}$ & 0.94 & 0.96 & -0.02 \\
\hline Always Wears Seatbelt ${ }^{a}$ & 0.67 & 0.66 & 0.01 \\
\hline White $^{\text {a }}$ & 0.78 & 0.76 & 0.02 \\
\hline Black $^{\text {a }}$ & 0.14 & 0.13 & 0.01 \\
\hline Native American ${ }^{a}$ & 0.02 & 0.02 & 0.00 \\
\hline Asian $^{\mathrm{a}}$ & 0.04 & 0.09 & -0.05 \\
\hline Other Race $^{a}$ & 0.05 & 0.03 & 0.01 \\
\hline Latino & 0.11 & 0.09 & 0.03 \\
\hline
\end{tabular}




\begin{tabular}{|c|c|c|c|}
\hline Other Parent Measures & & & \\
\hline Works $\mathrm{g}$ & 0.92 & 0.92 & 0.00 \\
\hline Unemployed $^{\mathrm{g}}$ & 0.01 & 0.00 & 0.01 \\
\hline Out of the Labor Force ${ }^{g}$ & 0.06 & 0.08 & -0.01 \\
\hline White ${ }^{g}$ & 0.78 & 0.76 & 0.02 \\
\hline Black ${ }^{g}$ & 0.11 & 0.09 & 0.02 \\
\hline Native American ${ }^{g}$ & 0.01 & 0.00 & 0.01 \\
\hline$A \operatorname{sian}^{g}$ & 0.05 & 0.11 & -0.06 \\
\hline Other Race ${ }^{g}$ & 0.06 & 0.05 & 0.01 \\
\hline Latino $^{\mathrm{h}}$ & 0.09 & 0.09 & 0.00 \\
\hline Alcohol Frequency ${ }^{\mathrm{i}}$ & 1.48 & 1.67 & -0.19 \\
\hline Parent Reported Child Measures & & & \\
\hline Birth Weight (ounces) ${ }^{j}$ & 119.42 & 117.18 & 2.24 \\
\hline Special Education Service - past year ${ }^{k}$ & 0.08 & 0.09 & -0.01 \\
\hline Mentally Retarded ${ }^{1}$ & 0.00 & 0.00 & 0.00 \\
\hline Learning Disability ${ }^{\mathrm{m}}$ & 0.10 & 0.16 & -0.05 \\
\hline $\mathrm{N}$ - Number of Pairs & 221 & & 94 \\
\hline $\mathrm{Na}$ & 220 & & 94 \\
\hline $\mathrm{Nb}$ & 221 & & 93 \\
\hline $\mathrm{N} \mathrm{c}$ & 211 & & 89 \\
\hline $\mathrm{N} \mathrm{d}$ & 217 & & 91 \\
\hline $\mathrm{Ne}$ & 220 & & 93 \\
\hline $\mathrm{Nf}$ & 215 & & 91 \\
\hline $\mathrm{Ng}$ & 172 & & 76 \\
\hline $\mathrm{Nh}$ & 169 & & 76 \\
\hline $\mathrm{Ni}$ & 171 & & 73 \\
\hline $\mathrm{N} \mathrm{j}$ & 198 & & 79 \\
\hline $\mathrm{Nk}$ & 213 & & 91 \\
\hline $\mathrm{N} 1$ & 214 & & 91 \\
\hline $\mathrm{N} \mathrm{m}$ & 212 & & 90 \\
\hline
\end{tabular}

Source: Add Health Data Waves I and IV. Includes same sex singleton full sibling pairs with complete information about parental income (Wave I), individual income (Wave IV), and genetic sensitivity score (Wave IV).

No differences between means of discordant and concordant sibling pairs are significant (at $p<0.05$ or $p<0.10$, twotailed t-test). 
Table S3: Family Fixed Effects Regressions Predicting Young Adult Financial Outcomes: Alternative GSS Measures

Panel A

\begin{tabular}{|c|c|c|c|c|c|c|c|c|}
\hline VARIABLES & $\begin{array}{c}(1) \\
\sqrt{\mathrm{Hh}} \\
\text { Income }\end{array}$ & $\begin{array}{c}(2) \\
\% \mathrm{FPL}\end{array}$ & $\begin{array}{c}(3) \\
\sqrt{ } \text { Earnings }\end{array}$ & $\begin{array}{c}\text { (4) } \\
\text { IHS Hh } \\
\text { Net Worth }\end{array}$ & $\begin{array}{c}(5) \\
\sqrt{\mathrm{Hh}} \\
\text { Income }\end{array}$ & $\begin{array}{c}(6) \\
\% \mathrm{FPL}\end{array}$ & $\begin{array}{c}(7) \\
\sqrt{\text { Earnings }}\end{array}$ & $\begin{array}{c}(8) \\
\text { IHS Hh } \\
\text { Net Worth }\end{array}$ \\
\hline GSS Alternate 1 & $\begin{array}{c}-28.44 * * \\
(8.51)\end{array}$ & $\begin{array}{c}-78.44 * * \\
(24.19)\end{array}$ & $\begin{array}{l}-24.77 * \\
(10.25)\end{array}$ & $\begin{array}{c}1.34 \\
(1.34)\end{array}$ & & & & \\
\hline GSS Alternate $1 \times \sqrt{ }$ Hh Income & $\begin{array}{c}0.10 * * \\
(0.03)\end{array}$ & $\begin{array}{c}0.35 * * \\
(0.10)\end{array}$ & $\begin{array}{l}0.10 * \\
(0.04)\end{array}$ & $\begin{array}{l}-0.00 \\
(0.01)\end{array}$ & & & & \\
\hline GSS Alternate 2 & & & & & $\begin{array}{c}-27.81 * * \\
(8.72)\end{array}$ & $\begin{array}{c}-75.34 * * \\
(25.02)\end{array}$ & $\begin{array}{l}-24.81 * \\
(10.64)\end{array}$ & $\begin{array}{c}1.40 \\
(1.37)\end{array}$ \\
\hline GSS Alternate $2 \times \sqrt{ }$ Hh Income & & & & & $\begin{array}{c}0.10 * * \\
(0.03)\end{array}$ & $\begin{array}{c}0.34 * * \\
(0.10)\end{array}$ & $\begin{array}{l}0.10 * \\
(0.04)\end{array}$ & $\begin{array}{l}-0.00 \\
(0.01)\end{array}$ \\
\hline Age & $\begin{array}{l}8.08 * * \\
(1.91)\end{array}$ & $\begin{array}{l}12.74 * \\
(6.04)\end{array}$ & $\begin{array}{l}8.08 * * \\
(1.86)\end{array}$ & $\begin{array}{c}0.25 \\
(0.31)\end{array}$ & $\begin{array}{l}8.17 * * \\
(1.91)\end{array}$ & $\begin{array}{l}12.96 * \\
(6.04)\end{array}$ & $\begin{array}{l}8.15^{* *} \\
(1.86)\end{array}$ & $\begin{array}{c}0.24 \\
(0.31)\end{array}$ \\
\hline Constant & $\begin{array}{c}21.31 \\
(56.61)\end{array}$ & $\begin{array}{c}-3.32 \\
(179.60)\end{array}$ & $\begin{array}{l}-64.02 \\
(56.66)\end{array}$ & $\begin{array}{l}-4.50 \\
(9.14)\end{array}$ & $\begin{array}{c}17.16 \\
(56.77)\end{array}$ & $\begin{array}{c}-17.07 \\
(179.61)\end{array}$ & $\begin{array}{l}-68.40 \\
(56.55)\end{array}$ & $\begin{array}{l}-4.61 \\
(9.18)\end{array}$ \\
\hline Observations & 630 & 624 & 624 & 564 & 630 & 624 & 624 & 564 \\
\hline R-squared & 0.08 & 0.04 & 0.07 & 0.01 & 0.08 & 0.04 & 0.07 & 0.01 \\
\hline Number of Sibling Pairs & 315 & 312 & 312 & 282 & 315 & 312 & 312 & 282 \\
\hline
\end{tabular}

GSS Alternate 1 is an index of 2-, 3-, or 5-repeat MAOA alleles, short 5-HTT alleles, 6- through 10-repeat DRD4 alleles, 10- through 13-repeat DAT1 alleles, and DRD2 A1 alleles.

GSS Alternate 2 is an index of 2-, 3-, or 5-repeat MAOA alleles, short 5-HTT alleles, 7-repeat DRD4 alleles, 10-repeat DAT1 alleles, and DRD2 A1 alleles.

Source: Add Health Data Waves I and IV. Sibling sample includes same sex singleton full sibling pairs with complete information about parental income (Wave I), individual income (Wave IV), and genetic sensitivity score (Wave IV).

Robust standard errors in parentheses, adjusted for family level clustering.

$+\mathrm{p}<0.1, * \mathrm{p}<0.05, * * \mathrm{p}<0.01$ 
Panel B

\begin{tabular}{|c|c|c|c|c|c|c|c|c|}
\hline VARIABLES & $\begin{array}{c}(1) \\
\sqrt{\mathrm{Hh}} \\
\text { Income }\end{array}$ & $\begin{array}{c}(2) \\
\% \mathrm{FPL}\end{array}$ & $\begin{array}{c}(3) \\
\sqrt{ } \text { Earnings }\end{array}$ & $\begin{array}{c}\text { (4) } \\
\text { IHS Hh } \\
\text { Net Worth }\end{array}$ & $\begin{array}{c}(5) \\
\sqrt{H h} \\
\text { Income }\end{array}$ & $\begin{array}{c}(6) \\
\% \mathrm{FPL}\end{array}$ & $\begin{array}{c}(7) \\
\sqrt{\text { Earnings }}\end{array}$ & $\begin{array}{c}(8) \\
\text { IHS Hh } \\
\text { Net Worth }\end{array}$ \\
\hline
\end{tabular}

GSS Alternate 3

$\begin{array}{cccc}-27.33^{* *} & -74.55^{* *} & -23.20 * & 1.59 \\ (8.38) & (23.74) & (10.24) & (1.33) \\ 0.10 * * & 0.35^{* *} & 0.10^{*} & -0.01 \\ (0.03) & (0.10) & (0.04) & (0.01)\end{array}$

GSS Alternate 4

GSS Alternate $4 \times \sqrt{ }$ Hh Income

\begin{tabular}{|c|c|c|c|c|c|c|c|c|}
\hline \multirow[b]{2}{*}{ Age } & & & & & $(0.03)$ & $(0.11)$ & $(0.04)$ & $(0.01)$ \\
\hline & $8.11 * *$ & $12.75 *$ & $8.10 * *$ & 0.25 & $8.15^{* *}$ & $12.90 *$ & $8.14 * *$ & 0.24 \\
\hline & (1.91) & $(6.04)$ & (1.86) & $(0.31)$ & $(1.91)$ & $(6.03)$ & $(1.86)$ & $(0.31)$ \\
\hline \multirow{2}{*}{ Constant } & 16.37 & -19.42 & -67.68 & -4.91 & 15.24 & -21.91 & -70.07 & -4.64 \\
\hline & $(56.71)$ & $(180.20)$ & $(56.43)$ & $(9.14)$ & $(56.66)$ & $(179.75)$ & $(56.51)$ & $(9.16)$ \\
\hline Observations & 630 & 624 & 624 & 564 & 630 & 624 & 624 & 564 \\
\hline R-squared & 0.08 & 0.04 & 0.07 & 0.01 & 0.08 & 0.04 & 0.07 & 0.00 \\
\hline Number of Sibling Pairs & 315 & 312 & 312 & 282 & 315 & 312 & 312 & 282 \\
\hline
\end{tabular}

GSS Alternate 3 is an index of 2- or 3-repeat MAOA alleles, short 5-HTT alleles, 6- through 10-repeat DRD4 alleles, 10-repeat DAT1 alleles, and DRD2 A1 alleles.

GSS Alternate 4 is an index of 2- or 3-repeat MAOA alleles, short 5-HTT alleles, 7-repeat DRD4 alleles, 10- through 13-repeat DAT1 alleles, and DRD2 A1 alleles.

Source: Add Health Data Waves I and IV. Sibling sample includes same sex singleton full sibling pairs with complete information about parental income (Wave I), individual income (Wave IV), and genetic sensitivity score (Wave IV).

Robust standard errors in parentheses, adjusted for family level clustering.

$+\mathrm{p}<0.1, * \mathrm{p}<0.05, * * \mathrm{p}<0.01$ 
Panel C

\begin{tabular}{lcccr}
\hline VARIABLES & $\begin{array}{c}(1) \\
\sqrt{\mathrm{Hh}} \\
\text { Income }\end{array}$ & $\begin{array}{c}(2) \\
\% \text { FPL }\end{array}$ & $\begin{array}{c}(3) \\
\sqrt{\text { Earnings }}\end{array}$ & $\begin{array}{c}(4) \\
\text { IHS H } \\
\text { Net Wo }\end{array}$ \\
\hline GSS Alternate 5 & & & & \\
GSS Alternate 5 x $\sqrt{\text { Hh Income }}$ & $-27.43^{* *}$ & $-75.27^{* *}$ & $-24.14^{*}$ & 1.50 \\
& $(8.38)$ & $(23.57)$ & $(10.25)$ & $(1.34)$ \\
& $0.10^{* *}$ & $0.34^{* *}$ & $0.10^{*}$ & -0.01 \\
GSS Alternate 6 & $(0.03)$ & $(0.10)$ & $(0.04)$ & $(0.01)$
\end{tabular}

GSS Alternate 6

GSS Alternate $6 \times \sqrt{ }$ Hh Income

\begin{tabular}{|c|c|c|c|c|c|c|c|c|}
\hline \multirow{3}{*}{ Age } & & & & & $(0.03)$ & $(0.10)$ & $(0.04)$ & $(0.01)$ \\
\hline & $8.11 * *$ & $12.79 *$ & $8.09 * *$ & 0.25 & $8.14 * *$ & $12.93 *$ & $8.13 * *$ & 0.24 \\
\hline & $(1.91)$ & $(6.04)$ & $(1.86)$ & $(0.31)$ & $(1.91)$ & $(6.04)$ & $(1.86)$ & $(0.31)$ \\
\hline \multirow[t]{2}{*}{ Constant } & 19.77 & -9.21 & -65.04 & -4.70 & 18.88 & -10.83 & -67.30 & -4.42 \\
\hline & $(56.69)$ & $(179.86)$ & $(56.56)$ & $(9.15)$ & $(56.67)$ & $(179.41)$ & $(56.66)$ & $(9.18)$ \\
\hline Observations & 630 & 624 & 624 & 564 & 630 & 624 & 624 & 564 \\
\hline R-squared & 0.08 & 0.04 & 0.07 & 0.01 & 0.08 & 0.04 & 0.07 & 0.00 \\
\hline Number of Sibling Pairs & 315 & 312 & 312 & 282 & 315 & 312 & 312 & 282 \\
\hline
\end{tabular}

GSS Alternate 5 is an index of 2-, 3-, or 5-repeat MAOA alleles, short 5-HTT alleles, 6- through 10-repeat DRD4 alleles, 10-repeat DAT1 alleles, and DRD2 A1 alleles.

GSS Alternate 6 is an index of 2-, 3-, or 5-repeat MAOA alleles, short 5-HTT alleles, 7-repeat DRD4 alleles, 10- through 13-repeat DAT1 alleles, and DRD2 A1 alleles.

Source: Add Health Data Waves I and IV. Sibling sample includes same sex singleton full sibling pairs with complete information about parental income (Wave I), individual income (Wave IV), and genetic sensitivity score (Wave IV).

Robust standard errors in parentheses, adjusted for family level clustering.

$+\mathrm{p}<0.1, * \mathrm{p}<0.05, * * \mathrm{p}<0.01$ 
Panel D

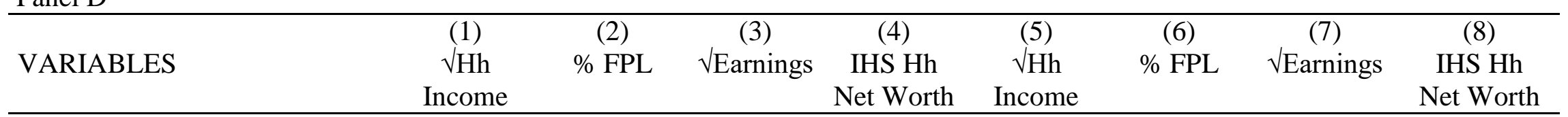

GSS Alternate 7

$\begin{array}{cccc}-28.36 * * & -77.77 * * & -23.84 * & 1.43 \\ (8.52) & (24.35) & (10.24) & (1.33) \\ 0.11 * * & 0.35 * * & 0.10 * & -0.00 \\ (0.03) & (0.10) & (0.04) & (0.01)\end{array}$

GSS Extended 1

GSS Extended $1 \mathrm{x} \sqrt{ } \mathrm{Hh}$ Income

\begin{tabular}{|c|c|c|c|c|c|c|c|c|}
\hline Age & $\begin{array}{c}8.09 * * \\
(1.91)\end{array}$ & $\begin{array}{l}12.72 * \\
(6.03)\end{array}$ & $\begin{array}{c}8.08^{* *} \\
(1.86)\end{array}$ & $\begin{array}{c}0.25 \\
(0.31)\end{array}$ & $\begin{array}{c}(0.03) \\
8.30 * * \\
(1.93)\end{array}$ & $\begin{array}{c}13.33 * \\
(6.13)\end{array}$ & $\begin{array}{l}(0.02) \\
8.31 * * \\
(1.86)\end{array}$ & $\begin{array}{c}(0.00) \\
0.21 \\
(0.31)\end{array}$ \\
\hline Constant & $\begin{array}{c}17.82 \\
(56.64)\end{array}$ & $\begin{array}{c}-13.89 \\
(179.96)\end{array}$ & $\begin{array}{l}-66.75 \\
(56.53)\end{array}$ & $\begin{array}{l}-4.71 \\
(9.13)\end{array}$ & $\begin{array}{c}24.88 \\
(58.57)\end{array}$ & $\begin{array}{c}6.76 \\
(182.22)\end{array}$ & $\begin{array}{l}-70.02 \\
(55.69)\end{array}$ & $\begin{array}{l}-0.94 \\
(9.36)\end{array}$ \\
\hline Observations & 630 & 624 & 624 & 564 & 630 & 624 & 624 & 564 \\
\hline R-squared & 0.08 & 0.04 & 0.07 & 0.01 & 0.07 & 0.02 & 0.07 & 0.01 \\
\hline Number of Sibling Pairs & 315 & 312 & 312 & 282 & 315 & 312 & 312 & 282 \\
\hline
\end{tabular}

GSS Alternate 7 is an index of 2- or 3-repeat MAOA alleles, short 5-HTT alleles, 6- through 10-repeat DRD4 alleles, 10- through 13-repeat DAT1 alleles, and DRD2 A1 alleles.

GSS Extended 1 is an index of 2- or 3-repeat MAOA alleles, short 5-HTT alleles, 7-repeat DRD4 alleles, 10-repeat DAT1 alleles, DRD2 A1 alleles, COMT A alleles, DRD5 148-bp alleles, rs12945042 (between 5-HTT and BLMH) indicator for two T alleles, MAOA-CA 115-bp and above alleles

Source: Add Health Data Waves I and IV. Sibling sample includes same sex singleton full sibling pairs with complete information about parental income (Wave I), individual income (Wave IV), and genetic sensitivity score (Wave IV).

Robust standard errors in parentheses, adjusted for family level clustering.

$+\mathrm{p}<0.1, * \mathrm{p}<0.05, * * \mathrm{p}<0.01$ 
Panel E

\begin{tabular}{|c|c|c|c|c|c|c|c|c|}
\hline VARIABLES & $\begin{array}{c}(1) \\
\sqrt{H h} \\
\text { Income }\end{array}$ & $\begin{array}{c}(2) \\
\% \text { FPL }\end{array}$ & $\begin{array}{c}(3) \\
\sqrt{\text { Earnings }}\end{array}$ & $\begin{array}{c}\text { (4) } \\
\text { IHS Hh } \\
\text { Net Worth }\end{array}$ & $\begin{array}{c}(5) \\
\sqrt{\mathrm{Hh}} \\
\text { Income }\end{array}$ & $\begin{array}{c}(6) \\
\% \mathrm{FPL}\end{array}$ & $\begin{array}{c}(7) \\
\sqrt{\text { Earnings }}\end{array}$ & $\begin{array}{c}(8) \\
\text { IHS Hh } \\
\text { Net Worth }\end{array}$ \\
\hline
\end{tabular}

\section{GSS Extended 2}

GSS Extended $2 \times \sqrt{ }$ Hh Income

\section{GSS Extended 3}

$\begin{array}{cccc}-15.30 * & -30.18+ & -19.28 * * & 1.14 \\ (6.40) & (16.86) & (5.61) & (0.81) \\ 0.05 * & 0.13+ & 0.08 * * & -0.01+ \\ (0.03) & (0.07) & (0.02) & (0.00)\end{array}$

GSS Extended $3 \times \sqrt{ }$ Hh Income

Age

\section{Constant}

$8.26 * *$

(1.93)

23.30

(58.57)

\section{Observations}

630

R-squared

0.07

315

Number of Sibling Pairs

$312 \quad 312$

Income

Net Worth alleles, DRD5 148-bp alleles, rs12945042 (between 5-HTT and BLMH) indicator for two T alleles, MAOA-CA over 115-bp alleles

GSS Extended 3 is an index of 2- or 3-repeat MAOA alleles, short 5-HTT alleles, 7-repeat DRD4 alleles, 10-repeat DAT1 alleles, DRD2 A1 alleles, COMT A alleles, DRD5 148-bp alleles, rs12945042 (between 5-HTT and BLMH) indicator for two T alleles, MAOA-CA 115-bp alleles

Source: Add Health Data Waves I and IV. Sibling sample includes same sex singleton full sibling pairs with complete information about parental income (Wave I), individual income (Wave IV), and genetic sensitivity score (Wave IV).

Robust standard errors in parentheses, adjusted for family level clustering.

$+\mathrm{p}<0.1, * \mathrm{p}<0.05, * * \mathrm{p}<0.01$ 
Table S4: Family Fixed Effects Regressions Predicting Young Adult Financial Outcomes: Interaction Sensitivity Score

\begin{tabular}{lcccc}
\hline VARIABLES & $\begin{array}{c}(1) \\
\sqrt{\mathrm{Hh}} \\
\text { Income }\end{array}$ & $\begin{array}{c}(2) \\
\% \mathrm{FPL}\end{array}$ & $\begin{array}{c}(3) \\
\sqrt{\text { Earnings }}\end{array}$ & $\begin{array}{c}(4) \\
\text { IHS Hh } \\
\text { Net Worth }\end{array}$ \\
\hline Genetic Sensitivity Interaction Score & $-38.19^{* *}$ & $-93.00^{* *}$ & $-42.52^{* *}$ & 0.71 \\
& $(13.63)$ & $(31.34)$ & $(16.30)$ & $(5.53)$ \\
GSIS x $\sqrt{ }$ Hh Income & $0.16^{* *}$ & $0.45^{* *}$ & $0.18^{*}$ & -0.01 \\
& $(0.05)$ & $(0.11)$ & $(0.07)$ & $(0.02)$ \\
Age & $8.23^{* *}$ & $13.35^{*}$ & $8.24 * *$ & 0.22 \\
Constant & $(1.93)$ & $(6.13)$ & $(1.87)$ & $(0.31)$ \\
& 4.17 & -3.88 & -70.19 & -2.91 \\
\hline Observations & $(55.26)$ & $(175.15)$ & $(53.38)$ & $(8.79)$ \\
R-squared & 630 & 624 & 624 & 564 \\
Number of Sibling Pairs & 0.06 & 0.02 & 0.06 & 0.00 \\
\hline
\end{tabular}

Source: Add Health Data Waves I and IV. Sibling sample includes same sex singleton full sibling pairs with complete information about parental income (Wave I), individual income (Wave IV), and genetic sensitivity score (Wave IV).

GSIS = Genetic Sensitivity Interaction Score; created by interacting the number of long DAT1 alleles, long DRD4 alleles, short MAOA alleles, short 5-HTT alleles, and DRD2 A1 alleles an individual carries.

Robust standard errors in parentheses, adjusted for family level clustering.

$+\mathrm{p}<0.1, * \mathrm{p}<0.05, * * \mathrm{p}<0.01$ 
Table S5: Family Fixed Effects Regressions Predicting Young Adult Financial Outcomes: Including Additional Controls

\begin{tabular}{|c|c|c|c|c|c|c|c|c|}
\hline VARIABLES & $\begin{array}{c}(1) \\
\sqrt{\mathrm{Hh}} \\
\text { Income } \\
\end{array}$ & $\begin{array}{c}(2) \\
\% \mathrm{FPL}\end{array}$ & $\begin{array}{c}(3) \\
\sqrt{ } \text { Earnings }\end{array}$ & $\begin{array}{c}(4) \\
\text { IHS Hh } \\
\text { Net Worth }\end{array}$ & $\begin{array}{c}(5) \\
\sqrt{H h} \\
\text { Income } \\
\end{array}$ & $\begin{array}{c}(6) \\
\% \mathrm{FPL}\end{array}$ & $\begin{array}{c}(7) \\
\sqrt{ } \text { Earnings }\end{array}$ & $\begin{array}{c}(8) \\
\text { IHS Hh } \\
\text { Net Worth } \\
\end{array}$ \\
\hline Genetic Sensitivity Score & $\begin{array}{c}-32.48 * * \\
(11.87)\end{array}$ & $\begin{array}{c}-92.60^{*} \\
(38.48)\end{array}$ & $\begin{array}{c}-30.05 * * \\
(10.25)\end{array}$ & $\begin{array}{c}1.64 \\
(1.76)\end{array}$ & $\begin{array}{c}-33.77 * * \\
(10.99)\end{array}$ & $\begin{array}{c}-97.50 * * \\
(34.60)\end{array}$ & $\begin{array}{c}-32.49 * * \\
(10.68)\end{array}$ & $\begin{array}{c}1.63 \\
(1.78)\end{array}$ \\
\hline GSS $x \sqrt{ }$ Hh Income & $\begin{array}{c}0.14 * * \\
(0.05)\end{array}$ & $\begin{array}{c}0.45^{* *} \\
(0.15)\end{array}$ & $\begin{array}{l}0.14 * * \\
(0.04)\end{array}$ & $\begin{array}{l}-0.00 \\
(0.01)\end{array}$ & $\begin{array}{c}0.14 * * \\
(0.04)\end{array}$ & $\begin{array}{l}0.47 * * \\
(0.13)\end{array}$ & $\begin{array}{c}0.15 * * \\
(0.05)\end{array}$ & $\begin{array}{l}-0.00 \\
(0.01)\end{array}$ \\
\hline Age & $\begin{array}{c}2.12 \\
(5.16)\end{array}$ & $\begin{array}{c}-8.73 \\
(15.75)\end{array}$ & $\begin{array}{l}9.77+ \\
(5.28)\end{array}$ & $\begin{array}{l}-0.59 \\
(0.95)\end{array}$ & $\begin{array}{c}2.35 \\
(5.21)\end{array}$ & $\begin{array}{c}-6.40 \\
(15.30)\end{array}$ & $\begin{array}{l}9.68+ \\
(5.22)\end{array}$ & $\begin{array}{l}-0.81 \\
(0.97)\end{array}$ \\
\hline Birth Weight (log ounces) & $\begin{array}{c}15.61 \\
(31.94)\end{array}$ & $\begin{array}{c}88.83 \\
(115.42)\end{array}$ & $\begin{array}{c}34.70 \\
(36.83)\end{array}$ & $\begin{array}{c}7.01 \\
(5.08)\end{array}$ & $\begin{array}{c}-39.25 \\
(107.44)\end{array}$ & $\begin{array}{l}-445.85 \\
(403.75)\end{array}$ & $\begin{array}{c}-7.29 \\
(127.45)\end{array}$ & $\begin{array}{l}39.53^{*} \\
(16.27)\end{array}$ \\
\hline Older Sibling & $\begin{array}{c}10.74 \\
(15.41)\end{array}$ & $\begin{array}{c}48.90 \\
(47.56)\end{array}$ & $\begin{array}{c}-6.94 \\
(14.67)\end{array}$ & $\begin{array}{c}2.35 \\
(2.64)\end{array}$ & $\begin{array}{l}-10.53 \\
(22.91)\end{array}$ & $\begin{array}{l}-30.29 \\
(72.27)\end{array}$ & $\begin{array}{c}-8.29 \\
(21.29)\end{array}$ & $\begin{array}{c}4.89 \\
(3.58)\end{array}$ \\
\hline Self-Reported Parental Favoritism & $\begin{array}{c}-12.77+ \\
(7.57)\end{array}$ & $\begin{array}{c}-30.30 \\
(25.37)\end{array}$ & $\begin{array}{c}-13.45^{*} \\
(5.79)\end{array}$ & $\begin{array}{l}-2.14 * \\
(1.02)\end{array}$ & $\begin{array}{l}-19.19 \\
(22.78)\end{array}$ & $\begin{array}{l}-43.17 \\
(71.12)\end{array}$ & $\begin{array}{c}-32.91+ \\
(17.30)\end{array}$ & $\begin{array}{l}-5.77 \\
(3.58)\end{array}$ \\
\hline Birth Weight $\mathrm{x} \sqrt{ }$ Hh Income & & & & & $\begin{array}{c}0.23 \\
(0.43)\end{array}$ & $\begin{array}{c}2.25 \\
(1.79)\end{array}$ & $\begin{array}{c}0.18 \\
(0.56)\end{array}$ & $\begin{array}{l}-0.14^{*} \\
(0.07)\end{array}$ \\
\hline Older $x \sqrt{ }$ Hh Income & & & & & $\begin{array}{c}0.08 \\
(0.07)\end{array}$ & $\begin{array}{c}0.30 \\
(0.26)\end{array}$ & $\begin{array}{c}0.00 \\
(0.07)\end{array}$ & $\begin{array}{l}-0.01 \\
(0.01)\end{array}$ \\
\hline Favoritism $x \sqrt{ }$ Hh Income & & & & & $\begin{array}{c}0.02 \\
(0.09)\end{array}$ & $\begin{array}{c}0.03 \\
(0.28)\end{array}$ & $\begin{array}{c}0.08 \\
(0.07)\end{array}$ & $\begin{array}{c}0.02 \\
(0.01)\end{array}$ \\
\hline Constant & $\begin{array}{c}98.24 \\
(219.80) \\
\end{array}$ & $\begin{array}{c}125.06 \\
(669.68) \\
\end{array}$ & $\begin{array}{l}-293.91 \\
(206.46)\end{array}$ & $\begin{array}{r}-16.96 \\
(37.41) \\
\end{array}$ & $\begin{array}{c}88.50 \\
(224.67) \\
\end{array}$ & $\begin{array}{c}12.72 \\
(684.86) \\
\end{array}$ & $\begin{array}{l}-292.77 \\
(212.80)\end{array}$ & $\begin{array}{c}-7.77 \\
(38.02) \\
\end{array}$ \\
\hline Obse & 456 & 450 & 452 & 411 & 456 & 450 & 452 & 411 \\
\hline R-squared & 0.09 & 0.06 & 0.12 & 0.04 & 0.10 & 0.08 & 0.13 & 0.07 \\
\hline Number of Sibling Pairs & 269 & 266 & 267 & 240 & 269 & 266 & 267 & 240 \\
\hline
\end{tabular}

Source: Add Health Data Waves I and IV. Sibling sample includes same sex singleton full sibling pairs with complete information about parental income (Wave I), individual income (Wave IV), and genetic sensitivity score (Wave IV).

Robust standard errors in parentheses, adjusted for family level clustering.

$+\mathrm{p}<0.1, * \mathrm{p}<0.05, * * \mathrm{p}<0.01$ 
Table S6: Family Fixed Effects Regressions Predicting Young Adult Financial Outcomes: By Parental Education and \% Federal Poverty Level

\begin{tabular}{|c|c|c|c|c|c|c|c|c|}
\hline VARIABLES & $\begin{array}{c}(1) \\
\sqrt{H h} \\
\text { Income } \\
\end{array}$ & $\begin{array}{c}(2) \\
\% \mathrm{FPL}\end{array}$ & $\begin{array}{c}(3) \\
\sqrt{ } \text { Earnings }\end{array}$ & $\begin{array}{c}\text { (4) } \\
\text { IHS Hh } \\
\text { Net Worth } \\
\end{array}$ & $\begin{array}{c}(5) \\
\sqrt{\mathrm{Hh}} \\
\text { Income }\end{array}$ & $\begin{array}{c}(6) \\
\% \mathrm{FPL}\end{array}$ & $\begin{array}{c}(7) \\
\sqrt{\text { Earnings }}\end{array}$ & $\begin{array}{c}(8) \\
\text { IHS Hh } \\
\text { Net Worth }\end{array}$ \\
\hline Genetic Sensitivity Score & $\begin{array}{c}-60.19 * * \\
(22.82)\end{array}$ & $\begin{array}{c}-118.94+ \\
(66.74)\end{array}$ & $\begin{array}{c}-50.85^{*} \\
(23.00)\end{array}$ & $\begin{array}{l}-0.75 \\
(4.17)\end{array}$ & $\begin{array}{c}-12.46^{*} \\
(6.11)\end{array}$ & $\begin{array}{c}-23.62 \\
(18.65)\end{array}$ & $\begin{array}{l}-10.11 \\
(7.14)\end{array}$ & $\begin{array}{c}0.83 \\
(0.77)\end{array}$ \\
\hline GSS x Average Parental Education & $\begin{array}{l}4.40^{*} \\
(1.74)\end{array}$ & $\begin{array}{l}9.70+ \\
(5.20)\end{array}$ & $\begin{array}{l}3.91 * \\
(1.73)\end{array}$ & $\begin{array}{c}0.08 \\
(0.32)\end{array}$ & & & & \\
\hline GSS x \% FPL & & & & & $\begin{array}{l}0.04 * \\
(0.02)\end{array}$ & $\begin{array}{l}0.12 * \\
(0.06)\end{array}$ & $\begin{array}{l}0.04 * \\
(0.02)\end{array}$ & $\begin{array}{l}-0.00 \\
(0.00)\end{array}$ \\
\hline Age & $\begin{array}{c}7.67 * * \\
(1.81)\end{array}$ & $\begin{array}{l}11.44 * \\
(5.71)\end{array}$ & $\begin{array}{l}7.15^{* *} \\
(1.85)\end{array}$ & $\begin{array}{c}0.12 \\
(0.29)\end{array}$ & $\begin{array}{c}8.56 * * \\
(1.96)\end{array}$ & $\begin{array}{l}14.50 * \\
(6.40)\end{array}$ & $\begin{array}{l}8.70 * * \\
(2.06)\end{array}$ & $\begin{array}{c}0.32 \\
(0.31)\end{array}$ \\
\hline Constant & $\begin{array}{c}29.84 \\
(53.00)\end{array}$ & $\begin{array}{c}19.21 \\
(169.82)\end{array}$ & $\begin{array}{l}-40.87 \\
(55.66)\end{array}$ & $\begin{array}{l}-1.63 \\
(8.69)\end{array}$ & $\begin{array}{c}7.44 \\
(58.41)\end{array}$ & $\begin{array}{c}-65.55 \\
(194.94)\end{array}$ & $\begin{array}{l}-89.23 \\
(63.52) \\
\end{array}$ & $\begin{array}{l}-6.60 \\
(9.44)\end{array}$ \\
\hline Observations & 713 & 705 & 703 & 639 & 536 & 532 & 530 & 482 \\
\hline R-squared & 0.06 & 0.02 & 0.05 & 0.00 & 0.08 & 0.03 & 0.07 & 0.01 \\
\hline Number of Sibling Pairs & 358 & 354 & 353 & 321 & 268 & 266 & 265 & 241 \\
\hline
\end{tabular}

Source: Add Health Data Waves I and IV. Sibling sample includes same sex singleton full sibling pairs with complete information about parental income (Wave I), individual income (Wave IV), and genetic sensitivity score (Wave IV).

Robust standard errors in parentheses, adjusted for family level clustering.

$+\mathrm{p}<0.1, * \mathrm{p}<0.05, * * \mathrm{p}<0.01$ 
Table S7: Family Fixed Effects Regressions Predicting Young Adult Financial Outcomes: By Race

\begin{tabular}{|c|c|c|c|c|c|c|c|c|}
\hline \multirow[b]{3}{*}{ VARIABLES } & (1) & (2) & (3) & (4) & (5) & (6) & (7) & (8) \\
\hline & \multicolumn{4}{|c|}{ White } & \multicolumn{4}{|c|}{ Black } \\
\hline & $\begin{array}{c}\sqrt{\mathrm{Hh}} \\
\text { Income }\end{array}$ & $\% \mathrm{FPL}$ & $\sqrt{\text { Earnings }}$ & $\begin{array}{c}\text { HIS Hh } \\
\text { Net Worth }\end{array}$ & $\begin{array}{c}\sqrt{\mathrm{Hh}} \\
\text { Income }\end{array}$ & $\%$ FPL & $\sqrt{\text { Earnings }}$ & $\begin{array}{l}\text { IHS Hh } \\
\text { Net Worth }\end{array}$ \\
\hline Genetic Sensitivity Score & $\begin{array}{c}-28.90 * * \\
(10.60)\end{array}$ & $\begin{array}{c}-83.24 * \\
(32.25)\end{array}$ & $\begin{array}{c}-26.34 * \\
(12.99)\end{array}$ & $\begin{array}{c}1.83 \\
(1.55)\end{array}$ & $\begin{array}{c}-29.68+ \\
(16.39)\end{array}$ & $\begin{array}{c}-61.73+ \\
(34.62)\end{array}$ & $\begin{array}{c}1.08 \\
(17.33)\end{array}$ & $\begin{array}{l}-4.83 \\
(2.97)\end{array}$ \\
\hline GSS $x \sqrt{ }$ Hh Income & $\begin{array}{c}0.10 * * \\
(0.04)\end{array}$ & $\begin{array}{c}0.36^{* *} \\
(0.12)\end{array}$ & $\begin{array}{l}0.12 * \\
(0.05)\end{array}$ & $\begin{array}{l}-0.01 \\
(0.01)\end{array}$ & $\begin{array}{l}0.16^{*} \\
(0.07)\end{array}$ & $\begin{array}{l}0.30+ \\
(0.15)\end{array}$ & $\begin{array}{l}-0.06 \\
(0.08)\end{array}$ & $\begin{array}{l}0.03 * \\
(0.01)\end{array}$ \\
\hline Age & $\begin{array}{l}7.64 * * \\
(2.28)\end{array}$ & $\begin{array}{l}11.23 \\
(7.37)\end{array}$ & $\begin{array}{l}6.83 * * \\
(2.16)\end{array}$ & $\begin{array}{l}-0.16 \\
(0.34)\end{array}$ & $\begin{array}{c}13.43 * * \\
(4.78)\end{array}$ & $\begin{array}{c}18.86+ \\
(9.98)\end{array}$ & $\begin{array}{c}14.87 * * \\
(4.46)\end{array}$ & $\begin{array}{l}2.16^{*} \\
(0.84)\end{array}$ \\
\hline Constant & $\begin{array}{c}38.21 \\
(68.69)\end{array}$ & $\begin{array}{c}42.16 \\
(220.93)\end{array}$ & $\begin{array}{l}-40.18 \\
(65.38) \\
\end{array}$ & $\begin{array}{c}7.80 \\
(10.08)\end{array}$ & $\begin{array}{c}-171.61 \\
(141.79)\end{array}$ & $\begin{array}{c}-236.83 \\
(293.10)\end{array}$ & $\begin{array}{c}-228.75+ \\
(126.91)\end{array}$ & $\begin{array}{l}-59.95^{*} \\
(25.40)\end{array}$ \\
\hline Observations & 464 & 458 & 462 & 418 & 84 & 84 & 82 & 78 \\
\hline R-squared & 0.07 & 0.03 & 0.06 & 0.01 & 0.22 & 0.11 & 0.27 & 0.23 \\
\hline Number of Sibling Pairs & 232 & 229 & 231 & 209 & 42 & 42 & 41 & 39 \\
\hline
\end{tabular}

Source: Add Health Data Waves I and IV. Sibling sample includes same sex singleton full sibling pairs with complete information about parental income (Wave I), individual income (Wave IV), and genetic sensitivity score (Wave IV), alternatively limited to white and black siblings.

Robust standard errors in parentheses, adjusted for family level clustering.

$+\mathrm{p}<0.1, * \mathrm{p}<0.05, * * \mathrm{p}<0.01$ 


\section{Wisconsin Longitudinal Study Analyses}

To address potential concerns about the external validity of sibling comparisons in the Add Health data, I conduct supplementary analyses using data from the Wisconsin Longitudinal Study (WLS), which represents the Wisconsin high school graduating class of 1957. Although the WLS includes genotype information for an array of single nucleotide polymorphisms (SNPs) for both individuals and their siblings, the WLS analysis is supplementary because little research has been done about whether the SNPs collected are related to environmental sensitivity.

The WLS did not collect information on any polymorphisms that involve a variable number tandem repeat, which make up most of the polymorphisms included in the Add Health genetic sensitivity score. To allow some consistency with the Add Health score, which includes a variant of DRD2, genetic sensitivity score in the WLS is an index of the number of minor alleles (or less common variants) at two SNPs located at the DRD2 gene (the A allele of rs 17529477 and the C allele of rs4245147).

Child income and earnings are measured in 1975 for graduates and represent total household income and individual earnings in 1974. The vast majority of graduates in the WLS data were born in 1939, because they represented the Wisconsin high school graduating class of 1957. Income is therefore measured at age 35 for most graduates. For their randomly selected sibling, income and earnings are measured in 1977 and represent household income and individual earnings in 1976. The two-year difference in measurement is not ideal, but is the same for all siblings so the difference is unrelated to genotype or parental income. Net worth (of the individual and their spouse) is measured in 1992 for graduates and in 1993 for siblings. Parental income is a multi-year average of household income from tax data from 1957 to 1960. This value is converted to 1974 dollars based on the Bureau of Labor Statistics Inflation 
Calculator (http://www.bls.gov/data/inflation_calculator.htm) for consistency with the child measures of income and earnings. In the regression analyses, transformed measures are used to increase the normality of the data. Consistent with the Add Health analyses, income and earnings are transformed using the square root transformation and net worth is transformed using inverse hyperbolic sine.

The regression analysis is the same as that outlined for Add Health (see Equation 1). Ordinary least squares regressions are first fit to the full sample of graduates and siblings, controlling for age and sex. These estimates, however, could be biased due to the potential association between genes and environment. Therefore, family fixed effects models are then fit to a sample limited to same sex full sibling pairs.

Descriptive information about the WLS full and sibling samples are provided in Table S8. A striking difference compared to the Add Health data is the smaller income differences between those from high and low income households. In both raw and percentage terms, the gap in child household income between those with low and high income parents is smaller in the WLS than Add Health. The gap in parental income and child earnings is also smaller. This could reflect lower overall inequality in the decades of the WLS measures compared to the Add Health measures.

Table S9 provides regression results for the WLS analyses, comparable to the Add Health analyses in Tables 4 and 5. Similar to the Add Health results, the full WLS sample results are null but when including family fixed effects there is a significant interaction between GSS and parental income when predicting total household income $(\mathrm{p}<0.05)$. This interaction is marginally significant $(\mathrm{p}<0.10)$ when predicting individual earnings. Also similar to the Add Health results, there is no interaction when predicting net worth. 
Finally, separate family fixed effects regressions are fit when limiting the sibling sample to those with high and low income parents. Presented in Table S10, the results show some evidence that GSS increases income and earnings among those from high income backgrounds, particularly when limiting the sample to those above the $65^{\text {th }}$ percentile of parental income. Among those from low income backgrounds, however, there is no evidence that GSS reduces financial standing. In fact, when predicting household income among those below median parental income, GSS positively predicts household income.

The WLS offers limited ability to replicate Add Health findings because a comparable GSS is unavailable, the population of Wisconsin in the 1950s differs from the U.S. population represented in Add Health, and the social context (including inequality) at the time of the two surveys differed. To the extent that results are comparable, however, the WLS results offer some evidence consistent with the Add Health results. 
Table S8: Descriptive Statistics: Wisconsin Longitudinal Study Panel A: Full Sample

\begin{tabular}{|l|rr|rr|}
\hline & \multicolumn{2}{|c|}{ All } & Low Parent & High Parent \\
& Mean & Std Dev & Hh Income & Hh Income \\
\hline Total Household Income 1975 & 16978.27 & 11368.66 & 15724.42 & 18202.19 \\
Individual Earnings 1975 & 9270.38 & 10611.86 & 8707.79 & 9819.54 \\
Net Worth 1992+ & 254436.00 & 391675.50 & 222887.90 & 285636.30 \\
Genetic Sensitivity Score & 1.58 & 1.21 & 1.56 & 1.59 \\
Parental Household Income & 10679.75 & 10138.19 & 5688.99 & 15551.37 \\
Birth Year & 38.97 & 2.62 & 38.87 & 39.07 \\
Male & 0.48 & 0.50 & 0.49 & 0.47 \\
\hline N & 4553 & & 2249 & 2304 \\
N+ & 4149 & & 2063 & 2086 \\
\hline
\end{tabular}

Panel B: Sibling Sample

\begin{tabular}{|l|rr|rr|}
\hline & \multicolumn{2}{|c|}{ All } & Low Parent & \multicolumn{2}{c|}{ High Parent } \\
& Mean & Std Dev & Hh Income & Hh Income \\
\hline Total Household Income 1975 & 16771.55 & 11304.14 & 15846.59 & 17616.34 \\
Individual Earnings 1975 & 9314.56 & 11410.48 & 8509.40 & 10049.94 \\
Net Worth 1992+ & 246117.40 & 289936.10 & 241452.10 & 250434.50 \\
Genetic Sensitivity Score & 1.55 & 1.20 & 1.45 & 1.64 \\
Parental Household Income & 11381.02 & 13505.31 & 5825.50 & 16455.07 \\
Birth Year & 39.58 & 4.38 & 39.24 & 39.89 \\
Male & 0.47 & 0.50 & 0.45 & 0.50 \\
\hline N & 574 & & 274 & 300 \\
N+ & 516 & & 248 & 268 \\
\hline
\end{tabular}

Source: Wisconsin Longitudinal Study. Full sample includes those with complete individual and parent household income and genetic sensitivity score data. Sibling sample is limited to same sex, full siblings with complete information for both the graduate and the sibling. 
Table S9: Regressions Predicting Financial Outcomes: Wisconsin Longitudinal Study

\begin{tabular}{|c|c|c|c|c|c|c|}
\hline \multirow[b]{2}{*}{ VARIABLES } & \multicolumn{3}{|c|}{ Full Sample } & \multicolumn{3}{|c|}{ Sibling Sample } \\
\hline & $\begin{array}{c}(1) \\
\sqrt{ } \text { Hh Income } \\
\end{array}$ & $\begin{array}{c}(2) \\
\sqrt{\text { Earnings }} \\
\end{array}$ & $\begin{array}{c}(3) \\
\text { IHS Net Worth }\end{array}$ & $\begin{array}{c}(4) \\
\sqrt{ } \text { Hh Income } \\
\end{array}$ & $\begin{array}{c}(5) \\
\sqrt{\text { Earnings }} \\
\end{array}$ & $\begin{array}{c}(6) \\
\text { IHS Net Worth }\end{array}$ \\
\hline GSS & $\begin{array}{c}0.41 \\
(2.42)\end{array}$ & $\begin{array}{l}-0.25 \\
(2.27)\end{array}$ & $\begin{array}{c}0.03 \\
(0.07)\end{array}$ & $\begin{array}{l}-10.36 \\
(7.94)\end{array}$ & $\begin{array}{l}-8.85 \\
(7.31)\end{array}$ & $\begin{array}{c}0.37 \\
(0.56)\end{array}$ \\
\hline GSS $x \sqrt{ }$ Hh Income & $\begin{array}{l}-0.00 \\
(0.03)\end{array}$ & $\begin{array}{c}0.00 \\
(0.02)\end{array}$ & $\begin{array}{c}0.00 \\
(0.00)\end{array}$ & $\begin{array}{l}0.17 * \\
(0.07)\end{array}$ & $\begin{array}{l}0.12+ \\
(0.07)\end{array}$ & $\begin{array}{l}-0.00 \\
(0.01)\end{array}$ \\
\hline Birth Year & $\begin{array}{l}-1.02 * * \\
(0.27)\end{array}$ & $\begin{array}{l}-0.57 * \\
(0.25)\end{array}$ & $\begin{array}{c}-0.04 * * \\
(0.01)\end{array}$ & $\begin{array}{l}-1.43 * * \\
(0.51)\end{array}$ & $\begin{array}{l}-0.46 \\
(0.47)\end{array}$ & $\begin{array}{l}-0.04 \\
(0.03)\end{array}$ \\
\hline Male & $\begin{array}{l}8.99 * * \\
(1.35)\end{array}$ & $\begin{array}{c}81.73^{* *} \\
(1.24)\end{array}$ & $\begin{array}{c}0.44 * * \\
(0.07)\end{array}$ & & & \\
\hline$\sqrt{ }$ Hh Income & $\begin{array}{c}0.16^{* * *} \\
(0.04)\end{array}$ & $\begin{array}{l}0.08^{*} \\
(0.03)\end{array}$ & $\begin{array}{l}0.00 * * \\
(0.00)\end{array}$ & & & \\
\hline Constant & $\begin{array}{c}141.75 * * \\
(11.21)\end{array}$ & $\begin{array}{c}52.26 * * \\
(10.17)\end{array}$ & $\begin{array}{c}13.29 * * \\
(0.48)\end{array}$ & $\begin{array}{c}169.31 * * \\
(20.63)\end{array}$ & $\begin{array}{c}91.90 * * \\
(19.00)\end{array}$ & $\begin{array}{c}14.11^{* *} \\
(1.29)\end{array}$ \\
\hline Family Fixed Effects & $\mathrm{N}$ & $\mathrm{N}$ & $\mathrm{N}$ & $\mathrm{Y}$ & $\mathrm{Y}$ & $\mathrm{Y}$ \\
\hline Observations & 4,553 & 4,553 & 4,149 & 574 & 574 & 464 \\
\hline R-squared & 0.03 & 0.50 & 0.02 & 0.07 & 0.02 & 0.01 \\
\hline Number of Pairs & & & & 287 & 287 & 232 \\
\hline
\end{tabular}

Source: Wisconsin Longitudinal Study. Full sample includes all individuals with complete information about parental income (1957-60), individual income (1975), and genetic sensitivity score. Sibling sample includes same sex singleton full sibling pairs with complete information about parental income, individual income, and genetic sensitivity score.

GSS $=$ Genetic Sensitivity Score

Standard errors in parentheses, adjusted for family level clustering in Models 1-3

$+\mathrm{p}<0.1, * \mathrm{p}<0.05, * * \mathrm{p}<0.01$ 
Table S10: Genetic Sensitivity Score Coefficients in Family Fixed Effects Regressions Predicting Financial Outcomes: Wisconsin Longitudinal Study Sibling Sample

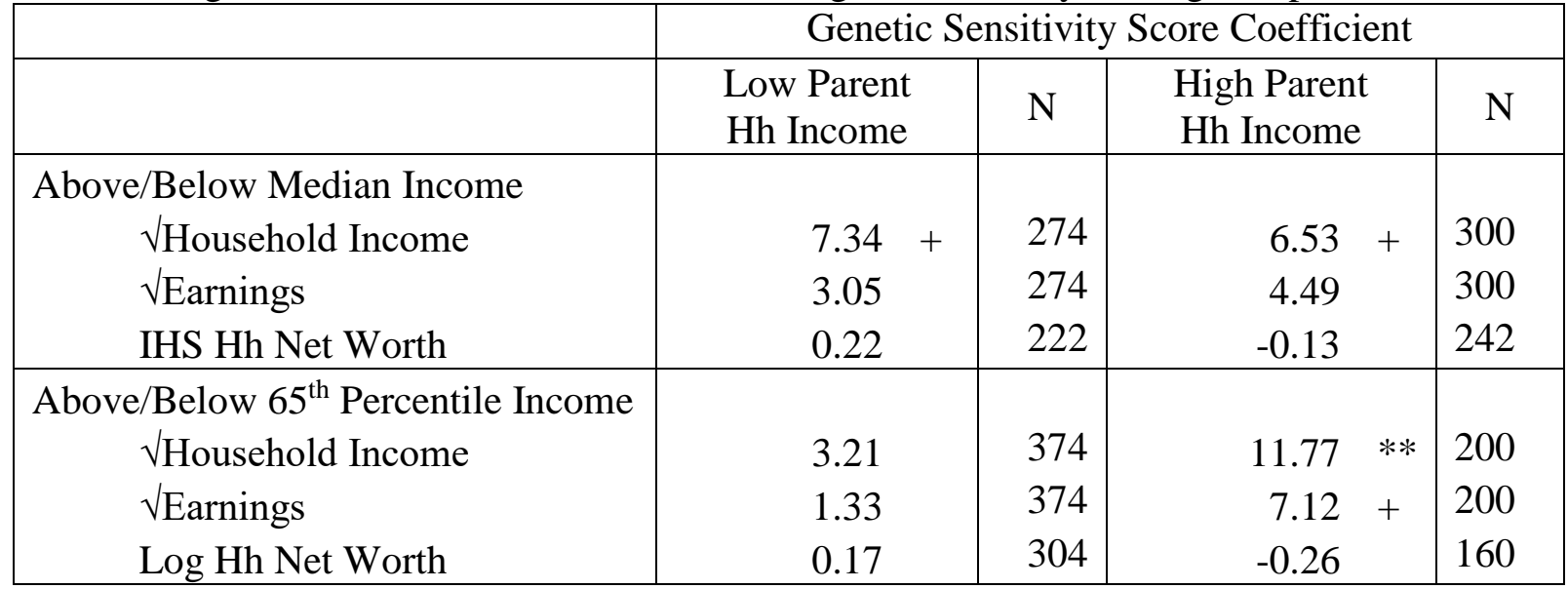

Source: Wisconsin Longitudinal Study. Full sample includes all individuals with complete information about parental income (1957-60), individual income (1975), and genetic sensitivity score. Sibling sample includes same sex singleton full sibling pairs with complete information about parental income, individual income, and genetic sensitivity score, limited to those with total parental income above and below the median parental income ( $\$ 9,100$ in 1975 dollars) or above and below $\$ 11,200$ (approximately $65^{\text {th }}$ percentile).

$+\mathrm{p}<0.1, * \mathrm{p}<0.05, * * \mathrm{p}<0.01$ 